NASA Technical Memorandum 107141

19960012178

AIAA-96-0636

\title{
Evaluation of Constant-Weber-Number Scaling for Icing Tests
}

David N. Anderson

Lewis Research Center

Cleveland, Ohio

Prepared for the

34th Aerospace Sciences Meeting and Exhibit sponsored by the American Institute of Aeronautics and Astronautics Reno, Nevada, January 15-18, 1996

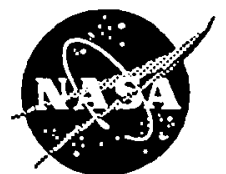

National Aeronautics and Space Administration

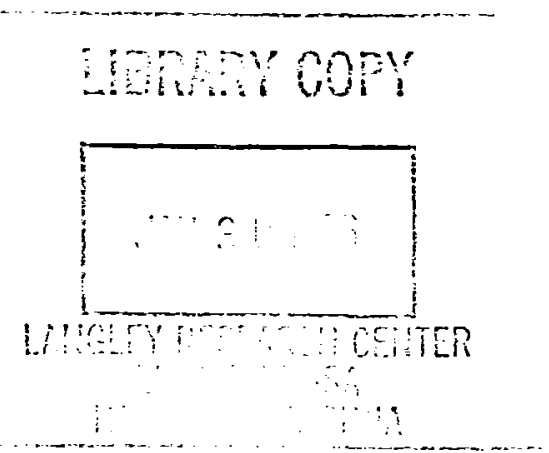




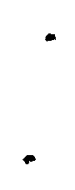




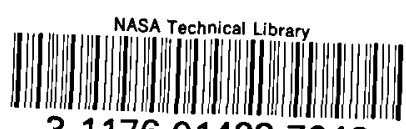

31176014237946

Evaluation of Constant-Weber-Number Scaling for Icing Tests

\author{
David N. Anderson \\ NASA Lewis Research Center \\ Cleveland, $\mathrm{OH}$
}

\begin{abstract}
Previous studies showed that for conditions simulating an aircraft encountering super-cooled water droplets the droplets may splash before freezing. Other surface effects dependent on the water surface tension may also influence the ice-accretion process. Consequently, the Weber number appears to be important in accurately scaling ice accretion. A scaling method which uses a constant-Weber-number approach has been described previously; this study provides an evaluation of this scaling method. Tests are reported on cylinders of 2.5 to $15-\mathrm{cm}$ diameter and NACA 0012 airfoils with chords of 18 to $53 \mathrm{~cm}$ in the NASA Lewis Icing Research Tunnel (IRT). The larger models were used to establish reference ice shapes, the scaling method was applied to determine appropriate scaled test conditions using the smaller models, and the ice shapes were compared. Icing conditions included warm glaze, horn glaze and mixed. The smallest size scaling attempted was $1 / 3$, and scale and reference ice shapes for both cylinders and airfoils indicated that the constant-Weber-number scaling method was effective for the conditions tested.
\end{abstract}

\section{Nomenclature}

$A_{c} \quad$ Accumulation parameter, dimensionless

$c \quad$ Cylinder diameter or $2 \times$ airfoil leading-edge radius, $\mathrm{cm}$

$c_{p} \quad$ Specific heat, cal/gm K

$h_{c} \quad$ Convective film heat-transfer coefficient, $\mathrm{cal} / \mathrm{sec} \mathrm{m}^{2} \mathrm{~K}$

$k \quad$ Thermal conductivity, cal/sec $\mathrm{m} \mathrm{K}$

$K_{0} \quad$ Modified droplet inertia parameter, dimensionless

LWC Liquid-water content, $\mathrm{g} / \mathrm{m}^{3}$

$M \quad$ Mach number, dimensionless

MVD Median volume droplet diameter, $\mu \mathrm{m}$

$n \quad$ Freezing fraction, dimensionless

$p \quad$ Ambient static pressure, $\mathrm{nt} / \mathrm{m}^{2}$

$p_{w} \quad$ vapor pressure of water, $\mathrm{nt} / \mathrm{m}^{2}$

$R_{a} \quad$ Gas constant for air, $287.0 \mathrm{nt} \mathrm{m} / \mathrm{kg} \mathrm{K}$

Re Reynolds number, dimensionless

$t \quad$ Temperature, ${ }^{\circ} \mathrm{C}$

$T \quad$ Absolute temperature, $\mathrm{K}$

$V \quad$ Airspeed, $\mathrm{m} / \mathrm{s}$

We Weber number, dimensionless

$\beta_{0} \quad$ Droplet collection efficiency, dimensionless

$\delta \quad$ Droplet median volume diameter, $\mu \mathrm{m}$

$\phi \quad$ Droplet-energy transfer term in energy equation, $\mathrm{K}$

$\theta \quad$ Air-energy transfer term in energy equation, $\mathrm{K}$

$A_{v} \quad$ Latent heat of vaporization, $\mathrm{cal} / \mathrm{gm}$

$\begin{array}{ll}\rho & \text { Density, } \mathrm{gm} / \mathrm{cm}^{3} \\ \mu & \text { Viscosity, } \mathrm{gm} / \mathrm{cm} \mathrm{s} \\ \tau & \text { Icing time, } \mathrm{min} \\ & \\ \text { Subscripts: } \\ a & \text { Air } \\ d & \text { Based on droplet size } \\ R & \text { Reference size and conditions } \\ s t & \text { Static } \\ \text { surf } & \text { Surface } \\ S & \text { Scale size and conditions } \\ t o t & \text { Total } \\ w & \text { Water }\end{array}$

\section{Introduction}

Icing wind tunnels are a valuable tool to simulate natural icing encounters to obtain data quickly and inexpensively. In contrast to flight testing, icing tunnels permit the selection and control of temperature and cloud conditions. However, tests in icing tunnels may also require significant compromises. In particular, limitations on model size often require that scaled test hardware be used, and limitations on coverage of the full FAR25 Appendix $\mathrm{C}$ may prevent testing at the desired liquid-water content, $L W C$, and median-volume droplet diameter, $d$.

A number of scaling laws have been proposed over the past 40 years in an effort to permit simulation of natural flight in icing tunnels. These laws, or methods, require that the scaled test conditions be chosen such that the values of several parameters important to ice accretion be matched to the respective full-size values. In this paper, the desired, or full-size conditions will be called the 'reference' conditions. Scaling laws have matched such parameters as the accumulation parameter, $A_{c}$, the modified droplet inertia parameter, $K_{0}$, and various terms included in the Messinger ${ }^{1}$ heat-balance equation, such as the freezing fraction. Scaling laws developed by Charpin and $\mathrm{Fasso}^{2}$ and by Ruff ${ }^{3}$ have been used extensively; however, they have been found to be less effective for glaze ice conditions than they are for rime $e^{4,5}$.

In 1988, Bilanin 6 published a Buckingham-p-Theorem analysis of icing and showed that in addition to the parameters traditionally considered in the development of scaling laws, the scale Mach, Reynolds and Weber numbers should also be matched to their respective reference, or full-size, values. In 1995, Bilanin and Anderson 7 showed inferential experimental evidence that droplet splashing on the surface during glaze ice accretions may be important. In that paper, a scaling method was presented in which the Weber number, We, was matched in 
addition to the parameters used in the traditional methods. By maintaining the same $W e$ between reference and scaled conditions, surface-water effects and interactions between impinging droplets and surface water for the scale test match those in the reference situation.

Reference 7 presented comparisons of ice shapes from tests performed with cylinders of $2.5-$ to $15-\mathrm{cm}$ diameter using the constant-We scaling method. Scale ice shapes generally matched reference shapes for sizes as small as $1 / 3$ the reference. However, in that study, experimental problems caused the test We for scale conditions to differ from the reference values by as much as $28 \%$. In the study reported here, several of those tests with cylinders were repeated with the $W e$ properly matched.

The droplet trajectory analysis used in the development of the scaling equations was derived by Langmuir and Blodgett ${ }^{8}$ for cylinders. To verify that the scaling equations also apply to airfoils, additional tests were performed as part of the present study using NACA 0012 airfoils of $53.3-\mathrm{cm}(21-\mathrm{in}), 26.7-\mathrm{cm}$ (10.5 in) and $17.8-\mathrm{cm}(7-\mathrm{in})$ chords. Tests with these models provided reference ice shapes (using the 53-cm chord) and $1 / 2$ and $1 / 3$ scaled results for comparison. Reference test conditions included air speeds of 67 and $89 \mathrm{~m} / \mathrm{s}$ (150 and $200 \mathrm{mph}$ ), total temperatures of -11 to $-4^{\circ} \mathrm{C}\left(12-24^{\circ} \mathrm{F}\right)$, water droplet sizes of 30 and $40 \mathrm{~mm}$ median-volume diameter, and cloud liquid-water contents of .55 to $1.0 \mathrm{~g} / \mathrm{m}^{3}$. These conditions produced mixed and glaze ice.

All tests were performed in the NASA Lewis Research Center Icing Research Tunnel (IRT). This paper compares the scale and reference ice shapes which resulted from these tests.

\section{Description of Experiment}

NASA Lewis Icing Research Tunnel. The IRT is shown in figure 1. It has been described in reference 9 . The IRT has a

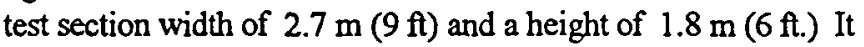
is capable of operation at test-section airspeeds of $160 \mathrm{~m} / \mathrm{s}$ ( 350 $\mathrm{mph}$ ) and higher, depending on model size. A refrigeration system permits accurate control of the test-section temperature from -40 to $4^{\circ} \mathrm{C}\left(-40\right.$ to $40^{\circ} \mathrm{F}$.) A water-spray system ${ }^{10}$ with 8 spray bars provides the ability to control test-section liquid-water content from .2 to $3 \mathrm{~g} / \mathrm{m}^{3}$ and droplet median volume diameters from 15 to $40 \mathrm{~mm}$.

Two sets of spray nozzles, known as the mod-1 and standard nozzles, are used in the IRT to provide different ranges of liquid-water content and droplet size ${ }^{10}$. For the present tests, only the mod-I nozzles were used.

Test Hardware. Ice accretion was measured on circular cylinders and NACA 0012 airfoils mounted in the center of the IRT test section. Hollow aluminum cylinders with 15.2-, 7.6-, 5.1- and 2.5-cm (6-, 3-, 2- and 1-in) outside diameters were used. Figure 2 shows how each cylinder was positioned in the IRT test section. A retractable shield was located in front of the cylinder to protect it from spray during the spray-bar start-up period when the water and air pressures were stabilizing. The shield was retracted rapidly into the tunnel ceiling by remote operation of a hydraulic actuator when the spray conditions had stabilized.

The NACA 0012 airfoils had chords of $53.3 \mathrm{~cm}(21 \mathrm{in}), 26.7 \mathrm{~cm}$ (10.5 in) and $17.8 \mathrm{~cm}(7 \mathrm{in})$. The $53.3-\mathrm{cm}$-chord airfoil was made of fiberglass while the 26.7 - and $17.8-\mathrm{cm}$-chord airfoils were machined from solid aluminum. Figure 3 shows the 53.3$\mathrm{cm}$-chord, full-span model mounted on the IRT turntable. Because of the way this airfoil was installed, the retractable shield could not be used with it.

The start-up shield was used with both of the smaller airfoils. Figure 4 shows the $26.7-\mathrm{cm}$-chord airfoil in the IRT test section with the shield. In Figure 4(a) the shield is lowered to protect the model from spray until cloud conditions became stable. Figure $4(\mathrm{~b})$ shows the shield raised to accrete ice on the model. The installation for the $17.8-\mathrm{cm}$-chord airfoil was identical. Both of these aluminum models had spans of $122 \mathrm{~cm}(4 \mathrm{ft})$.

All airfoils were mounted at $0^{\circ}$ angle of attack for these tests.

Test Procedure. Tests were performed by first establishing the desired velocity and temperature. Water spray was then initiated. When the shield was used, it was raised when the spray conditions had stabilized, and the spray timer was started at this time. When the shield was not used, $.2 \mathrm{~min}$ were added to the required spray time to adjust for the period of spray transient. When the prescribed spray period was completed, the spray was shut off and the tunnel brought to idle to permit personnel entry into the test section to trace the ice shape.

The ice shape was recorded by first melting a thin slice through the ice normal to the model span-wise axis. The shape was then traced onto a cardboard template; the shape was later digitized for computer storage to generate plots for comparisons. After the ice shape was recorded, the model was cleaned and the procedure repeated for the next spray condition.

Spray Stability. For each of the airfoil tests, tunnel and cloud conditions were recorded at 2-sec intervals. Recording started with the initiation of the icing cloud for tests in which the model shield was not used (i.e., tests with the 53.3-cm-chord airfoil only) and with the lifting of the shield in all other tests. These data provided a means to determine the time to stabilize the spray in the case of the non-shielded tests as well as a check of the stability of the icing spray for both shielded and non-shielded starts.

Figure 5 shows the cloud liquid-water-content history for a typical test without the start-up shield. The $L W C$ was calculated 
from the average tunnel velocity and the air pressure and waterair differential pressure for each spray bar at each recording interval. The calculation used calibration equations based on liquid-water content measurements in the IRT test section. The result for each spray bar is shown with a different symbol. The average of the $8 \mathrm{LWC}$ s increased rapidly to reach the set condition of $.55 \mathrm{~g} / \mathrm{m}^{3}$ in about $30 \mathrm{sec}$. After an overshoot of about $3 \%$, the $L W C$ returned to the set condition within $2 \mathrm{~min}$ of spray initiation. For tests with the shield, the typical range of $L W C$ variation after the shield was raised was $\pm .4 \%$. For all tests without the shield, desired spray times were increased by .2 min to compensate for the low LWC during the start-up transient. The desired spray time for the test of figure 5 was 9.9 $\min$ before adding the start-up transient allowance. When the average product of $L W C$ and time from Figure 5 was integrated over the actual 10.1-min spray time, it was found to be within $2.5 \%$ of the value of the desired product of $.55 \mathrm{~g} / \mathrm{m}^{3}$ and $9.9 \mathrm{~min}$. The spray times reported here are those without the $.2 \mathrm{~min}$ compensation.

Figure 6 gives the history of the $M V D$ for each of the 8 spray bars for the same 10-minute icing test without the start-up shield. As with the $L W C$ calculation, equations used were from calibrations of the cloud using drop-size measurements in the IRT test section. About 2 min was needed to achieve the required $40 \mu \mathrm{m}$ drop size with good stability. The average drop size for the cloud climbed to $35 \mu \mathrm{m}$ in less than $30 \mathrm{sec}$, overshot to $45 \mu \mathrm{m}$ in less than $1 \mathrm{~min}$ and reached $40 \mu \mathrm{m}$ again after about $2 \mathrm{~min}$. Thus, for $95 \%$ of the spray time, the drop size was within $\pm 5 \mu \mathrm{m}$ of the correct value. This result was typical of the unshielded tests reported here. For tests using the shield, the typical variation of $M V D$ was less than $\pm .1 \mu \mathrm{m}$ once the shield was raised to expose the model to the icing cloud.

Typical IRT velocity histories are shown in Figure 7. The velocity was computed from the total pressure and the total-static differential pressure measured with each of two pitot probes located on either side of the entrance to the IRT test section. Velocities for the unshielded test whose $L W C$ and MVD were given above is presented in Figure 7(a). The different symbols show how one pitot probe gave approximately $.7 \mathrm{~m} / \mathrm{s}(1.5 \mathrm{mph})$ higher velocity readings than the other. The minimum and maximum velocities calculated for this test differed by less than $2 \mathrm{~m} / \mathrm{s}(5 \mathrm{mph})$.

When the shield was used to protect the model from the icing cloud during spray stabilization, the test-section blockage was higher with the shield lowered than when it was raised. The change in blockage which occurred when the shield was raised required the tunnel operators to adjust the velocity. Figure $7(\mathrm{~b})$ shows a typical velocity history for a shielded-model test. Time started with the raising of the shield. Again, the two pitot probes gave velocities differing by about $.7 \mathrm{~m} / \mathrm{s}(1.5 \mathrm{mph})$. For this test the desired velocity was $88 \mathrm{~m} / \mathrm{s}(196 \mathrm{mph})$; this value was reached within about $30 \mathrm{sec}$ of raising the shield. The velocity stability exhibited in Figure 7(a) was never achieved, and the speed oscillated about the correct value for the duration of the test. However, the range from the minimum indicated from the lower-reading probe to the maximum from the higher was less than $3 \mathrm{~m} / \mathrm{s}(6 \mathrm{mph})$. Both the oscillation and the magnitude of fluctuation shown in Figure 7(b) was typical of velocity observations for other tests using the shield.

Uncertainty in Parameter Values. All test conditions reported are averages. When the shield was used to protect the model from spray during start-up, the averages were obtained after the shield was raised. For tests without the shield the average values of velocity, droplet size and liquid-water content were obtained after the stabilization of cloud conditions. To establish the total uncertanty in the velocity, droplet size and liquid-water content, the pressure transducer accuracy was combined with observed fluctuations in the measurements during each run. The maximum uncertainty in velocity was $\pm 2.7 \%$, in $M V D, \pm 13.4 \%$, and in $L W C, \pm 2.4 \%$.

The tunnel temperature was the average of 11 thermocouples located on the turning vanes just upstream of the spray bars. These thermocouples have an uncertainty of about $\pm .6^{\circ} \mathrm{C}$ $\left( \pm 1.5^{\circ} \mathrm{F}\right)$. In addition, stratification in the tunnel introduced an additional uncertainty of about $\pm .8^{\circ} \mathrm{C}\left( \pm 2^{\circ} \mathrm{F}\right)$. This can be seen in Figure 8 which gives typical histories of each of the 11 thermocouples located at turning-vane ' $D$ ' which is just upstream of the IRT spray bars. In this study, the test section temperature was not independently determined, and the temperatures reported are the averages of the 11 comer-' $D$ ' thermocouples. Thus, although some mixing of the flow may reduce the stratification, the uncertainty in temperature may be as much as $\pm 1.4^{\circ} \mathrm{C}\left( \pm 3.5^{\circ} \mathrm{F}\right)$.

\section{Scaling Equations}

Reference 6 proposed a scaling method in which the scale droplet trajectory, Weber number, $W e$, accumulation parameter, $A_{c}$, freezing fraction, $n$, and droplet energy transfer term, $\phi$, were matched with the respective reference values. This method is similar to the AEDC method derived by Ruff ${ }^{3}$ with the added restriction that $W e$ must be matched. The consequence of this restriction is that only the scale model size, $c_{S}$, can be chosen; the scale velocity, $V_{S}$ is determined by the $W e$. The $W e$ accounts for surface effects, and it is assumed that both $R e$ and $M$ can be neglected. The complete derivation is given in reference 6 , and the working equations will be repeated here.

The following four equations are first solved simultaneously to give the scale airspeed, $V_{S}$, scale static temperature, $T_{S}$, scale static pressure, $p_{S}$, and scale drop size, $\delta_{S}$ :

$$
V_{S}=V_{R}\left(\frac{\delta_{R}}{\delta_{S}}\right)^{\frac{1}{2}}
$$




$$
\begin{gathered}
T_{S}=T_{R}+\frac{V_{R}^{2}}{2 c_{p, w, \text { Nov }}}-\frac{V_{S}^{2}}{2 c_{p, w, w w j}} \\
p_{S}=\frac{p_{\text {tots } S}}{1+\frac{V_{S}^{2}}{2 R_{a} T_{S}}} \\
\delta_{S}=8_{R}\left(\frac{c_{S}}{c_{R}}\right)^{.62}\left(\frac{p_{S}}{p_{R}}\right)^{.24}\left(\frac{V_{S}}{V_{R}}\right)^{-38}
\end{gathered}
$$

The scale liquid-water content, $L W C_{S}$, was found by equating the scale and reference freezing fraction. The equation that results after equating scale and reference collection efficiency, $\beta_{0}$, and scale and reference droplet energy transfer term, $\phi$, is

$$
L W C_{S}=L W C_{R} \frac{\theta_{S}}{\theta_{R}} \frac{h_{c S S}}{h_{c, R}} \frac{V_{R}}{V_{S}}
$$

From the Messinger equation, $\theta$ is the air energy transfer term:

$$
\theta=T_{\text {sorf }}-T-r \frac{V^{2}}{2 c_{p, a}}+.693 \frac{\mathrm{gm} \mathrm{K}}{\text { joule }} \Lambda_{\nu} \frac{p_{\text {w, suff }}-p_{w}}{p}
$$

where $r$ is the recovery factor, taken as .875 in this analysis, $p_{w, s u r f}$ is the vapor pressure of water at the surface of the model (i.e., at $T_{\text {surf }}$ ) and $p_{w}$ is the vapor pressure of water in the atmosphere (i.e., at the absolute static temperature, $T$ ). The vapor pressures used for this study were from Pruppacher and Klett ${ }^{11}$.

The scale and reference convective heat transfer coefficients, $h_{c, S}$ and $h_{c, R}$, in equation (5) were evaluated using the following empirical expression from Gelder and Lewis ${ }^{12}$ :

$$
h_{c}=1.244 \frac{k_{a}}{c}\left(\frac{V c p_{a}}{\mu_{a}}\right)^{.4774}
$$

The final scale parameter needed is the spray time, $\tau$. It was found by equating the scale and reference accumulation parameters:

$$
\tau_{S}=\tau_{R} \frac{L W C_{R}}{L W C_{S}} \frac{V_{R}}{V_{S}} \frac{c_{S}}{c_{R}}
$$

Table I presents several reference conditions and the corresponding scaled conditions when equations (1) - (8) were used to apply constant-We scaling. Sizes were scaled to $1 / 2$ and $1 / 3$ of the reference values. Reference conditions were chosen to represent a range of ice types from near rime to warm glaze.

It was noted above that constant-We scaling permits only the choice of scale size, unlike traditional scaling methods which allow the choice of both scale size and airspeed. Table I illustrates some additional potential disadvantages of this method. First, the scale airspeed is always higher than the reference value. To simulate an icing encounter at $90 \mathrm{~m} / \mathrm{s}(200$ $\mathrm{mph}$ ) with a $1 / 3$-scale test requires a tunnel capable of operating at about $140 \mathrm{~m} / \mathrm{s}(310 \mathrm{mph})$. Mach-number effects, which have been neglected in this scaling method, are probably important for speeds much higher than this; thus, tests at scales smaller than $1 / 3$ are probably impractical unless very low airspeeds are to be simulated. Second, the high airspeeds produce high total temperatures which can approach and exceed the freezing point of water. When ice is accreted at near-freezing temperatures the adhesion of the ice to the surface is greatly reduced, and aerodynamic forces may affect the shape. These effects are not included in the constant-We analysis; therefore the method should not be used when temperatures approach freezing.

\section{Results}

The constant-Weber-number scaling method was tested in the IRT using the ice-accretion test techniques discussed earlier. Scaled conditions from Table I were used with cylinders and NACA 0012 airfoils. This section reports the ice shapes recorded from those tests. For each test the ice shape was recorded at 2 locations along the span of the model: at $91 \mathrm{~cm}$ ( 36 in) from the tunnel floor (i.e., at the tunnel centerline) and at $112 \mathrm{~cm}$ (44 in) (i.e., at $20 \mathrm{~cm}$ ( 8 in) above the tunnel centerline.) The cloud $L W C$ calibration ${ }^{10}$ was based at the center of the test section and cloud uniformity depends on tunnel airspeed; therefore, even with valid scaling methods, conditions which scale at the tunnel centerline may not scale elsewhere if the cloud uniformity changes significantly from reference to scale conditions. Thus, shapes at both locations will be reported. The $\mathrm{x}-\mathrm{y}$ coordinates of the scaled ice shapes were multiplied by the appropriate scale factor to permit direct comparison with the reference shapes. Average test conditions are given with each figure. 
Cylinder Tests. In the tests reported in reference 7 a transducer calibration error produced cloud conditions which gave scale $W e$ different from the reference values. Three tests from that study were repeated here with properly-scaled conditions. Cylinder tests were also made using reference conditions not reported in reference 7.

Figure 9 shows results for tests of case 1 in Table I. This was a warm-glaze condition. The reference ice shape for a $15.2-\mathrm{cm}$ diameter cylinder is shown as a solid line, and the $1 / 2$-scale test on a 7.6-cm cylinder is shown as a dashed line. Results for a second test of the $1 / 2$-scale condition, indicated with a dotted line, are given to show repeatability of the ice shape. Figure 9(a) gives the ice shapes recorded at the tunnel centerline position, and Figure 9(b) at $20 \mathrm{~cm}(8 \mathrm{in})$ above the centerline. The scale ice shapes at both locations matched the reference shapes within the repeatability indicated.

The conditions tested for Figure 10 resulted in ice shapes with horn spread varying along the cylinder span in a cyclic manner. The horn angle of the reference shape (solid line) can be seen to vary from the centerline to $20 \mathrm{~cm}$ above centerline. The hom angle for the $1 / 2$-scale test also varied and did not precisely coincide with the reference shape. The agreement at the centerline position was somewhat better than that at $20 \mathrm{~cm}(8 \mathrm{in})$ above the centerline.

Figure 11 gives results for a third case repeated from the tests of reference 7. This is again a warm glaze condition similar to that shown in Figure 9; however, the reference drop size for this test was $58 \mu \mathrm{m}$ and the reference cylinder diameter was half that of Figure 9 . Figure 11 (a) shows that the $2 / 3$ scale result matched the reference quite well while the $1 / 3$ scale shape gave only fair agreement at the tunnel center. No reference shape was recorded at $20 \mathrm{~cm}$ above the tunnel center, but it can be seen from Figure 11(b) that the $2 / 3$ and $1 / 3$ scale shapes appear to be similar.

The conditions reported in Figure 12 differed from those of Figure 11 in that the reference droplet size was reduced from 58 to $40 \mu \mathrm{m}$ and the liquid-water content was reduced from .89 to .8 $\mathrm{g} / \mathrm{m}^{3}$. The reference model was, again, a 7.6-cm (3-in) cylinder, for this test, only $2 / 3$-size scaling was possible because $1 / 3$ scaling produced conditions not achievable in the IRT. The reference test was repeated (solid and dashed lines). The repeatability was fair at the centerline (figure 12(a)) and excellent at the higher position (figure 12(b)). The match of the 2/3-scaled result (dotted line) was also excellent at both locations.

Finally, Figure 13 presents a $2 / 3$-size scaling test with the reference temperature reduced by $2.8^{\circ} \mathrm{C}\left(5^{\circ} \mathrm{F}\right)$ from the tests of Figure 12. Again, a repeat test was made at the reference condition. As for the conditions of figure 12 , repeatability at 20 $\mathrm{cm}(8 \mathrm{in})$ above the tunnel center was better than at the center. The 2/3-scaled test gave a tunnel-centerline ice shape that agreed better with the repeated reference test results than with the original reference shape. At the 20 -cm- (8-in-) abovecenterline location the scaled ice shape was a close match of both reference shapes.

Airfoil Tests. All airfoil tests used a 53.3-cm- (21-in-) chord NACA 0012 as the reference model. Scaled ice shapes were obtained from tests with 26.7-cm- (10.5-in-) and 17.8-cm- (7in-) chord NACA 0012 models ( $1 / 2$ and $1 / 3$ scale).

Figure 14 compares $1 / 2$-scale and 1/3-scale ice shapes with the reference shapes for a mixed ice shape at $89 \mathrm{~m} / \mathrm{s}(200 \mathrm{mph})$. Shapes from both of the scaled tests matched the reference shapes at the centerline (Fig. 14(a)) and at $20 \mathrm{~cm}$ above the centerline (Fig. 14(b)).

When the conditions of Figure 14 were repeated but with a $2.8^{\circ} \mathrm{C}\left(5^{\circ} \mathrm{F}\right)$ higher temperature, the hom-glaze condition shown in Figure 15 resulted. The horn-glaze ice shape is often difficult to reproduce in a scale test. The constant-We method produced fairly accurate scale shapes at the tunnel center (Fig. 15(a)). At $20 \mathrm{~cm}(8 \mathrm{in})$ above the centerline, the $1 / 2$-scale test reproduced the reference fairly well, but the $1 / 3$-scale test appeared to accrete too much ice.

An additional increase in temperature of $2.8^{\circ} \mathrm{C}\left(5^{\circ} \mathrm{F}\right)$ over the tests of Figure 15 gave the horn-glaze ice shape shown in Figure 16. Once again, the $1 / 2$-scale test simulated the reference ice shape very accurately while the 1/3-scale appeared to accreted too much ice at both locations on the model.

The test results given in Figure 17 are for a horn-glaze condition at $67 \mathrm{~m} / \mathrm{s}(150 \mathrm{mph})$. Both the $1 / 2$ - and $1 / 3$-scale tests gave shapes that agreed well with the reference at the tunnel center (Fig. 17(a)). At the 20-cm (8-in) position (Fig. 17(b)), both scale tests appeared to accrete somewhat too much ice.

An increase in temperature of $2.8^{\circ} \mathrm{C}\left(5^{\circ} \mathrm{F}\right)$ over that shown in figure 17 gave the ice shapes of Figure 18. Figure 18(a) shows that $1 / 2$ and $1 / 3$ scaling both gave excellent agreement with the reference ice shape. At $20 \mathrm{~cm}(8 \mathrm{in})$ above the centerline (Fig $18(b))$, the $1 / 2$-scale test gave only fair agreement with the reference while the 1/3-scale did not match.

Although the scaled ice shapes did not match the reference in every test, there was sufficient agreement to provide strong evidence of the validity of the constant-We scaling method.

\section{Concluding Remarks}

Tests have been performed using both cylinders and NACA 0012 aiffoils of various sizes to evaluate the constant-We scaling method. All models were mounted vertically in the IRT test section. Reference sizes included $15.2-\mathrm{cm}-(6-\mathrm{in}-)$ and $7.6-\mathrm{cm}-$ (3-in-) diameter cylinders and 53.3-cm- (21-in-) chord airfoils. Comparison tests with conditions determined by the constant-We 
method were made with models scaled to $2 / 3,1 / 2$ and $1 / 3$ the reference size. Reference conditions were chosen to produce a variety of accreted ice shapes including both rime and glaze ice. Ice-shape cross sections were recorded at two locations along the span of the model: at the center of the tunnel $(91.4 \mathrm{~cm}$ (36 in) from the floor) and at $20 \mathrm{~cm}(8 \mathrm{in})$ above the center. For most tests, scaled ice shapes with $2 / 3$ - and 1/2-size models closely matched the reference shapes. Somewhat less success was experienced with the 1/3-size tests, although many of these also matched the reference ice shapes.

As with many scaling techniques, the constant-We method requires the matching of the scale and reference freezing fraction. It was shown in this study that the uncertainty in tunnel temperature, on which the freezing fraction depends, may be as much as $\pm 1.4^{\circ} \mathrm{C}\left( \pm 4^{\circ} \mathrm{F}\right)$. It was shown in reference 5 that a change in temperature of this magnitude can have a significant effect on ice shape. Clearly, then, improvements in temperature measurement are needed for future scaling studies and for accurate testing using any scaling method.

In general, the best match of ice shapes was found at the midspan (tunnel center) position. The constant-We method requires increased airspeeds for reduced-size models, and the cloud uniformity in the IRT changes with airspeed ${ }^{10}$; consequently, scale and reference ice shapes recorded at the $20-\mathrm{cm}$ - (8-in-) above-midspan position matched less frequently than those from the mid-span position. Cloud uniformity could be a significant concern for scaling when it's necessary to determine ice shapes on more than just the midspan of the scaled model.

There is no definition at the present time of how closely ice shapes need to match to claim successful scaling. For this study, adequate scaling was assumed if scaled shapes agreed with reference shapes within the repeatability of those shapes. The evaluation was entirely subjective, however. In the absence of either a quantitative description of ice shapes or the identification of critical features of ice shapes, assessment of scaling methods will continue to be based on subjective judgement.

The success of the constant-We scaling method suggests that surface effects, which may include droplet splashing on impact, play a significant part in the ice-accretion process. A better understanding of such effects is needed to incorporate into iceaccretion-prediction models as well as scaling methods.

In reference 7 an excellent match of ice shapes was demonstrated for scaling tests even when the scale $W e$ was as much as $28 \%$ lower than the reference. When the scale $W e$ was carefully matched to the reference value for the present study, the agreement between scale and reference ice shapes was no better than shown in reference 7. Further study is needed to determine how much the constant-We conditions can be relaxed and still produce acceptable scaling.

\section{References}

1. Messinger, B.L., "Equilibrium Temperature of an Unheated Icing Surface as a Function of Airspeed," J. Aeron. Sci. 20 No. 1, Jan. 1953, pp 29-42.

2. Charpin, Francois and Fasso, Guy, "Icing Testing in the Large Modane Wind Tunnel on Full Scale and Reduced Scale Models," L'Aeronautique et l'Astronautique, no 38, 1972. English translation published as NASA TM-75373.

3. Ruff, G.A.: "Analysis and Verification of the Icing Scaling Equations," AEDC-TR-85-30, Vol 1 (Rev), March, 1986.

4. Anderson, David N.: "Rime-, Mixed- and Glaze-Ice Evaluations of Three Scaling Laws," AIAA 94-0718, January, 1994.

5. Anderson, David N.: "Methods for Scaling Icing Test Conditions," AIAA 95-0540 and NASA TM 106827, January, 1995.

6. Bilanin, A. J., "Proposed Modifications to the Ice Accretion/cing Scaling Theory," ALAA Paper AIAA-88-0203, January 1988.

7. Bilanin, Alan J. and Anderson, David N.: "Ice Accretion with Varying Surface Tension," AIAA 95-0538 and NASA TM 106826, January, 1995.

8. Langmuir, Irving and Blodgett, Katharine B.: "A Mathematical Investigation of Water Droplet Trajectories," Army Air Forces Technical Report No. 5418, February, 1946.

9. Soeder, Ronald $H$. and Andracchio, Charles, R., "NASA Lewis Icing Research Tunnel User Manual," NASA TM 102319, June 1990.

10. Ide, Robert F., "Liquid Water Content and Droplet Size Calibration of the NASA Lewis Icing Research Tunnel, "NASA TM 102447, Jan 1990.

11. Pruppacher, Hans R. and Klett, James D., Microphysics of Clouds and Precipitation, Reidel, Boston, 1980.

12. Gelder, Thomas F. and Lewis, James P.: "Comparison of Heat Transfer from Airfoil in Natural and Simulated Icing Conditions," NACA TN 2480, September, 1951. 
Table I

Constant-We Scaling Conditions

\begin{tabular}{|c|c|c|c|c|c|c|c|c|c|c|c|c|c|c|c|c|c|}
\hline case & & model & $\begin{array}{c}\text { chord } \\
\text { or } \\
\text { cyl } \\
\text { diam, } \\
\text { cm }\end{array}$ & $\begin{array}{c}\text { chord } \\
\text { or } \\
\text { cyl } \\
\text { diam, } \\
\text { in }\end{array}$ & $\begin{array}{l}t_{x x}, \\
{ }^{\circ} \mathrm{C}\end{array}$ & $\begin{array}{l}t_{10 t} \text {, } \\
{ }^{\circ} \mathrm{C}\end{array}$ & $\begin{array}{l}t_{m x}, \\
{ }^{\circ} F\end{array}$ & $\begin{array}{c}t_{\text {tot }} \text {, } \\
{ }^{\circ} \mathrm{F}\end{array}$ & $\begin{array}{c}V \\
\mathrm{~m} / \mathrm{sec}\end{array}$ & $\begin{array}{c}V, \\
\mathbf{m p h}\end{array}$ & $\begin{array}{c}M V D \\
\mu \mathrm{m}\end{array}$ & $\begin{array}{c}L W C, \\
\mathrm{~g} / \mathrm{m}^{3}\end{array}$ & $\begin{array}{c}\text { Time, } \\
\min \end{array}$ & $M$ & $\begin{array}{c}R e \\
x 10^{-5}\end{array}$ & $\mid \begin{array}{c}W e \\
\times 10^{-3}\end{array}$ & $n$ \\
\hline \multirow[t]{2}{*}{1} & reference & & 15.2 & 6 & -6.7 & -4.4 & 20.0 & 24.0 & 67.1 & 150.0 & 40.8 & 1.11 & 42.8 & 0.205 & 7.60 & 2.82 & 0.20 \\
\hline & $1 / 2 \mathrm{sc}$ & cylinder & 7.6 & 3 & -7.1 & -3.1 & 19.3 & 26.4 & 89.1 & 199.4 & 23.1 & 1.26 & 14.2 & 0.273 & 4.95 & $"$ & 1 \\
\hline \multirow[t]{2}{*}{2} & reference & cylinder & 15.2 & 6 & -12.2 & -8.2 & 10.0 & 17.2 & 89.5 & 200.0 & 40.7 & 0.88 & 40.3 & 0.276 & 10.27 & 5.00 & 0.35 \\
\hline & $1 / 2$ scale & cylinder & 7.6 & 3 & -12.9 & -6.0 & 8.8 & 21.1 & 117.4 & 262.7 & 23.6 & 0.98 & 13.8 & 0.363 & 6.54 & $n$ & " \\
\hline \multirow[t]{3}{*}{3} & refer & cylinder & 7.6 & 3 & -6.7 & -4.4 & 20.0 & 24.0 & 67.1 & 150.0 & 58.0 & 0.89 & 26.8 & 0.205 & 3.80 & 4.01 & 0.22 \\
\hline & $2 / 3 \mathrm{~s}$ & cylinder & 5.1 & 2 & -6.8 & -3.8 & 19.7 & 25.1 & 78.1 & \begin{tabular}{|l|}
174.8 \\
\end{tabular} & 42.7 & 0.96 & 14.2 & 0.239 & 2.93 & $"$ & \\
\hline & $1 / 3$ scale & cylinder & 2.5 & 1 & -7.4 & -2.2 & 18.7 & 28.1 & 102.4 & 229.0 & 24.9 & 1.03 & 5.0 & 0.313 & 1.87 & 1 & \\
\hline \multirow[t]{3}{*}{4} & reference & cylinder & 7.6 & 3 & -9.4 & -7.2 & 15.0 & 19.0 & 67.1 & 150.0 & 40.0 & 0.80 & 26.8 & 0.206 & 3.87 & 2.77 & 0.38 \\
\hline & $2 / 3$ scale & cylinder & 5.1 & 2 & -9.6 & -6.7 & 14.7 & 20.0 & 76.9 & \begin{tabular}{|l|}
172.1 \\
\end{tabular} & 30.4 & 0.87 & 14.3 & 0.241 & 2.99 & $"$ & \\
\hline & $1 / 3$ & cyli & 2.5 & 1 & -10.0 & -5.4 & 14.0 & 22.2 & 95.5 & 213.6 & 19.7 & 0.99 & 5.1 & 0.317 & 1.91 & $"$ & \\
\hline \multirow[t]{3}{*}{5} & refe & cylir & 7.6 & 3 & -6.7 & -4.4 & 20.0 & 24.0 & 67.1 & 150.0 & 40.0 & 0.80 & 26.8 & 0.205 & 3.80 & 2.77 & 0.26 \\
\hline & $2 / 3$ & & 5.1 & 2 & -6.8 & -3.9 & 19.7 & 25.0 & 76.9 & 172.1 & 30.4 & 0.86 & 14.4 & 0.240 & 2.94 & $"$ & $"$ \\
\hline & $1 / 3$ & cylinder & 2.5 & 1 & -7.2 & -2.7 & 19.0 & 27.2 & 95.5 & 213.6 & 19.7 & 0.95 & 5.3 & 0.315 & 1.88 & & \\
\hline \multirow[t]{3}{*}{6} & refe & airfoil & 53.3 & 21 & -15.0 & -11.0 & 5.0 & 12.2 & 89.4 & 200.0 & 40.0 & 0.55 & 9.9 & 0.278 & 1.74 & 4.92 & 0.82 \\
\hline & $1 / 2$ & airfoil & 26.7 & 10.5 & -15.7 & -8.8 & 3.7 & 16.2 & 117.9 & 263.7 & 23.0 & 0.62 & 3.4 & 0.367 & 1.11 & $"$ & " \\
\hline & $1 / 3$ & airfo & 17.8 & 7 & -16.3 & -6.8 & 2.6 & 19.8 & 138.6 & 310.1 & 16.6 & 0.64 & 1.8 & 0.431 & 0.85 & & $\bar{"}$ \\
\hline \multirow[t]{3}{*}{7} & refe & airfo & 53.3 & 21 & -12.2 & -8.2 & 10.0 & 17.2 & \begin{tabular}{|l|}
89.4 \\
\end{tabular} & 200.0 & 40.0 & 0.55 & 9.9 & 0.276 & 1.71 & 4.92 & 0.66 \\
\hline & $1 / 2$ & if & 26.7 & 10.5 & -12.9 & -6.0 & 8.7 & 21.2 & 117.8 & 263.6 & 23.0 & 0.61 & 3.4 & 0.364 & 1.09 & $"$ & \\
\hline & $1 / 3$ scale & airfoil & 17.8 & 7 & -13.6 & -4.0 & 7.6 & 24.8 & 138.5 & 309.9 & 16.7 & 0.62 & 1.9 & 0.429 & 0.83 & & 1 \\
\hline \multirow[t]{3}{*}{8} & refe & airfoil & 53.3 & 21 & -9.4 & -.5 .5 & 15.0 & 22.2 & 89.4 & 200.0 & 40.0 & 0.55 & 9.9 & 0.275 & 1.68 & 4.92 & 0.49 \\
\hline & $1 / 2$ & airfoil & 26.7 & 10.5 & -10.1 & -3.2 & 13.7 & 26.2 & 117.8 & 263.5 & 23.0 & 0.59 & 3.5 & 0.362 & 1.07 & $"$ & \\
\hline & $1 / 3$ & airf & 17.8 & 7 & -10.8 & -1.2 & 12.6 & 29.8 & 138.5 & 309.8 & 16.7 & 0.58 & 2.0 & 0.427 & 0.82 & & \\
\hline \multirow[t]{3}{*}{9} & refe & ainf & 53.3 & 21 & -11.1 & -8.9 & 12.0 & 16.0 & 67.1 & 150.0 & 40.0 & 0.65 & 11.2 & 0.207 & 1.30 & 2.77 & 0.65 \\
\hline & $1 / 2$ & airf & 26.7 & 10.5 & -11.5 & -7.6 & 11.3 & 18.3 & 87.9 & 196.7 & 23.3 & 0.76 & 3.7 & 0.271 & 0.84 & $"$ & $"$ \\
\hline & $1 / 3$ scale & & 17.8 & 7 & -11.8 & -6.5 & 10.7 & 20.2 & 103.0 & 230.5 & 16.9 & 0.81 & 2.0 & 0.318 & 0.65 & $"$ & $"$ \\
\hline \multirow[t]{3}{*}{10} & reference & airfoil & 53.3 & 21 & -8.3 & -6.1 & 17.0 & 21.0 & 67.1 & 150.0 & 40.0 & 0.65 & 11.2 & 0.206 & 1.28 & 2.77 & 0.48 \\
\hline & $1 / 2$ scale & airfoil & 26.7 & 10.5 & -8.7 & -4.9 & 16.3 & 23.2 & 87.9 & 196.7 & 23.3 & 0.74 & 3.7 & 0.270 & 0.82 & $"$ & $"$ \\
\hline & $1 / 3$ scale & airfoil & 17.8 & 7 & -9.1 & -3.8 & 15.7 & 25.2 & 103.0 & 230.5 & 16.9 & 0.78 & 2.0 & 0.316 & 0.63 & 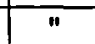 & \\
\hline
\end{tabular}




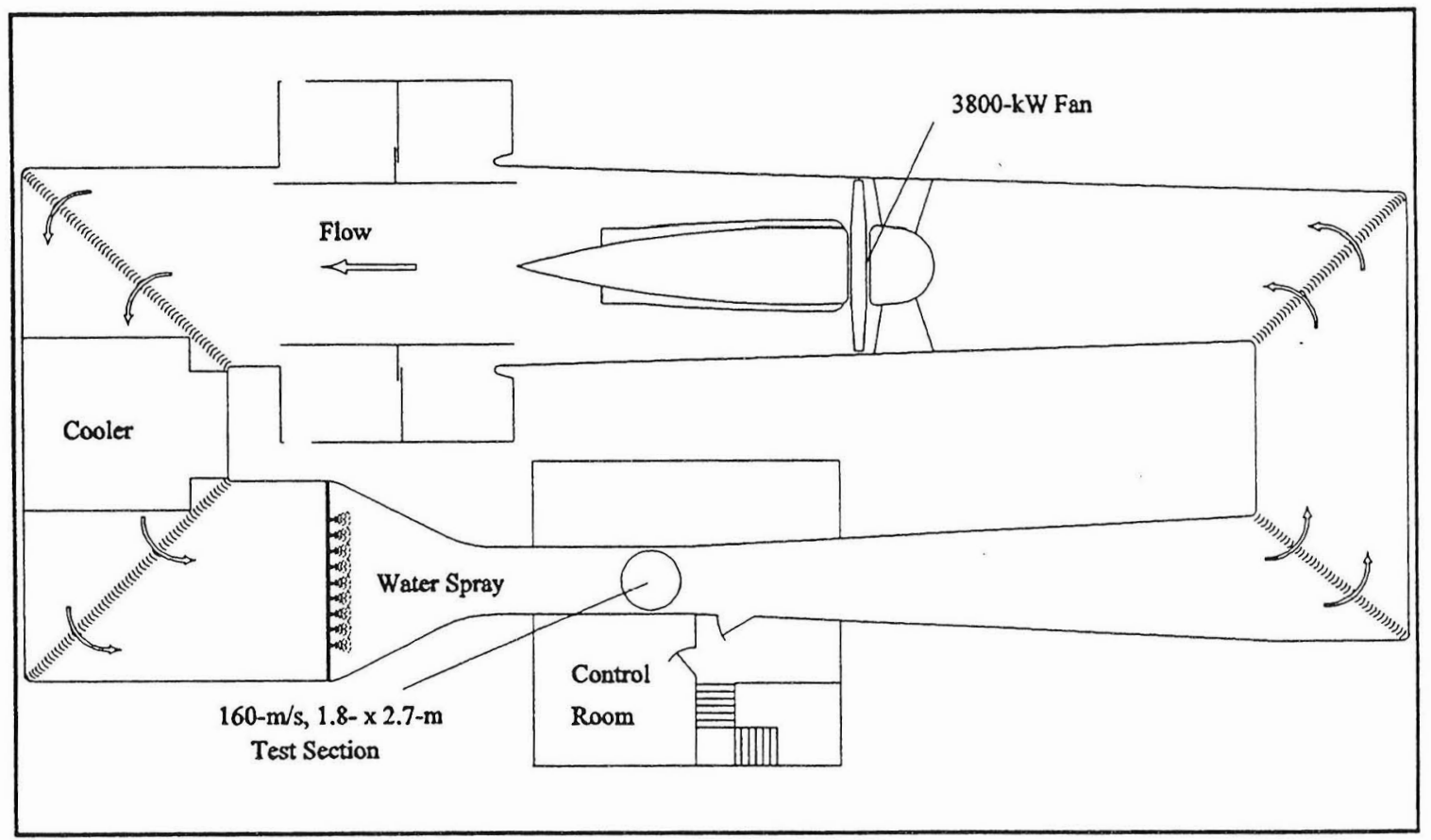

Figure 1. NASA Lewis Icing Research Tunnel (IRT).
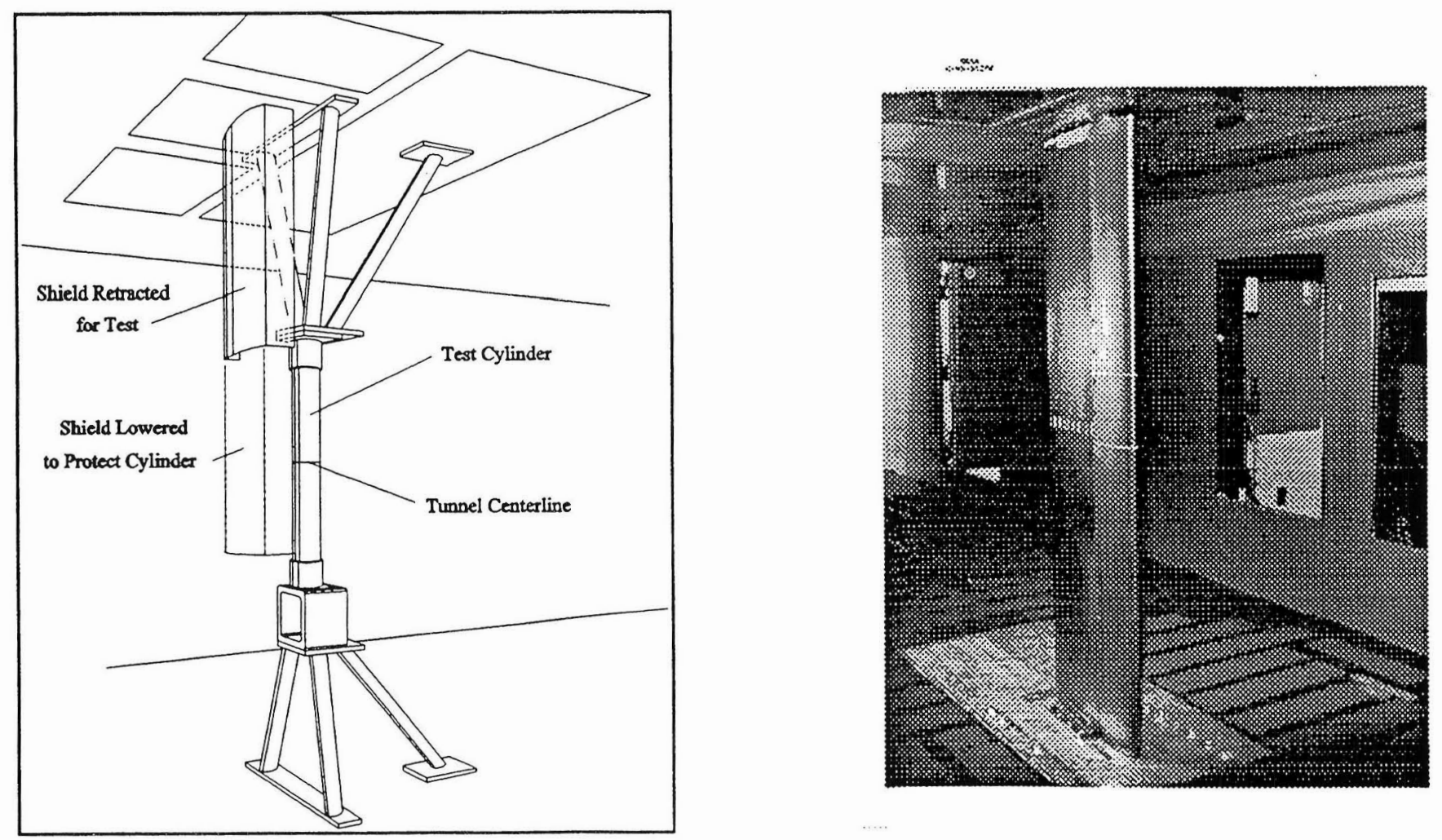

Figure 2. Test Cylinder and Shield Mounted in IRT.

Figure 3. 53.3-cm-chord NACA. 0012 Airfoil Installed in IRT Test Section. 


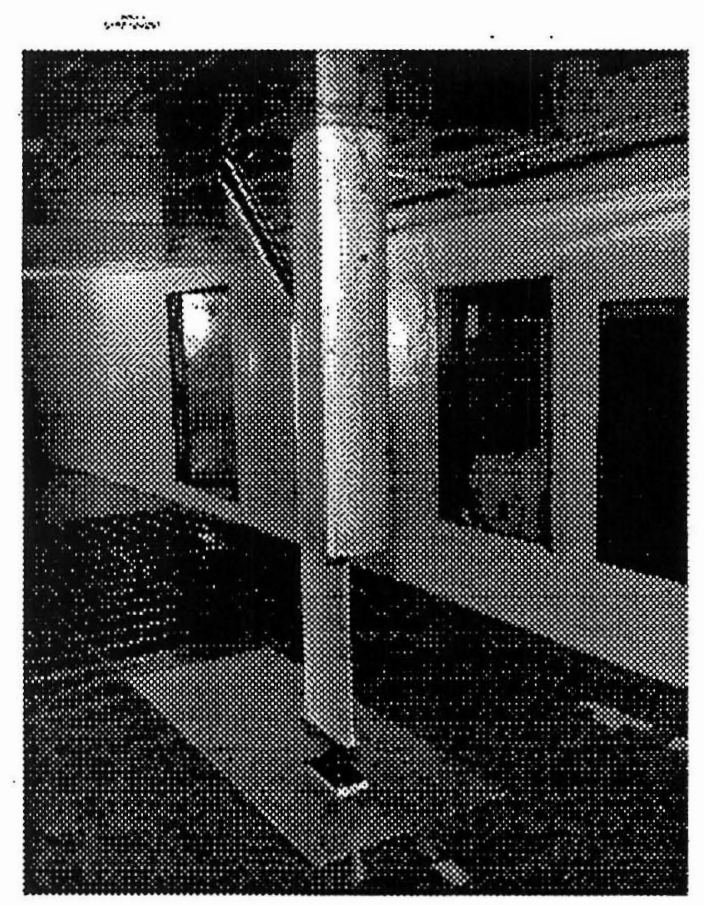

(a) Start-up Shield Lowered to Protect Model During Icing Spray Stabilization.

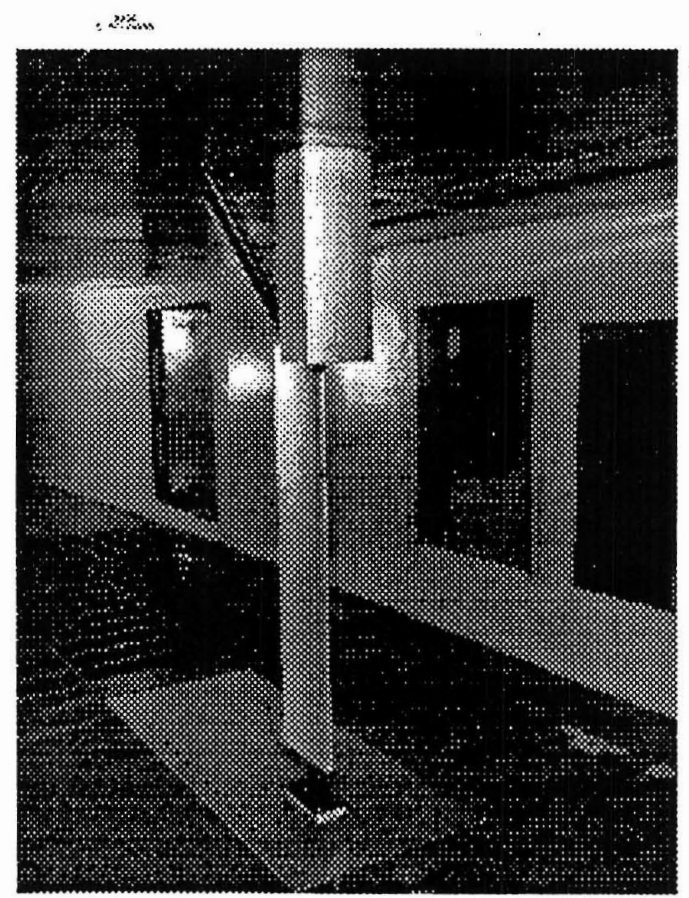

(b) Start-up Shield Raised to Expose Model to Spray.

Figure 4. 26.7-cm-chord NACA 0012 Airfoil Installed in IRT Test Section.

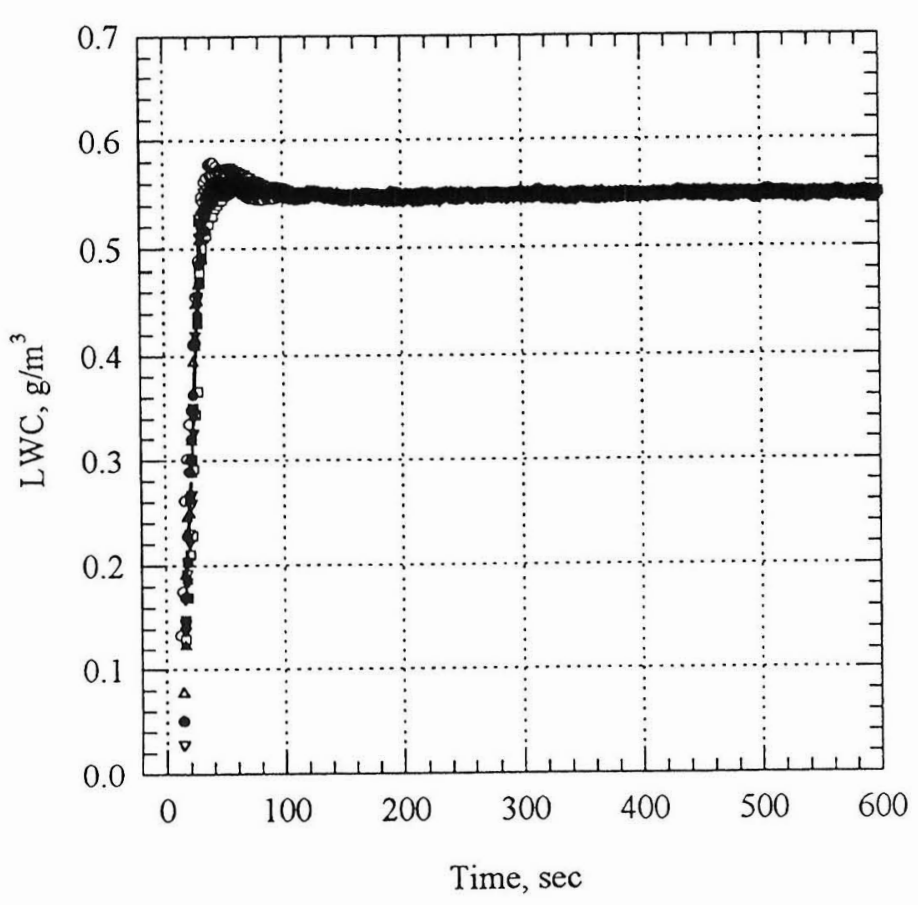

Figure 5. Liquid-Water-Content History in IRT During Typical 10-min Spray Without the Start-up Shield.

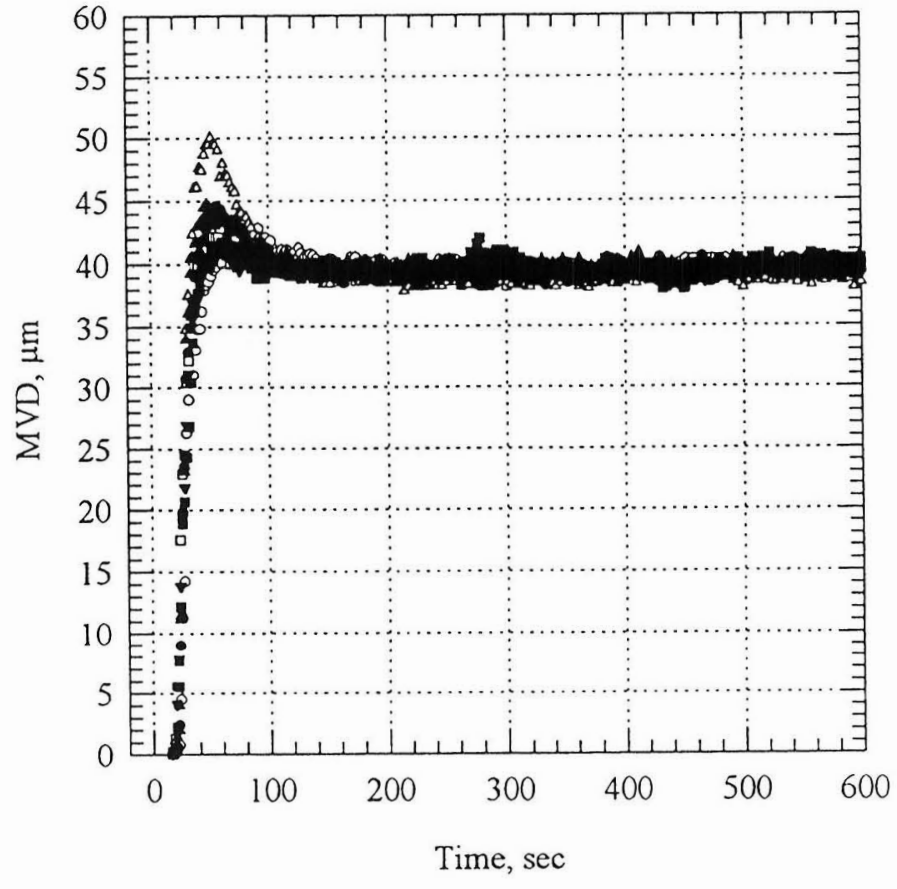

Figure 6. Droplet Size History in IRT During Typical 10-min Spray Without the Start-up Shield. 


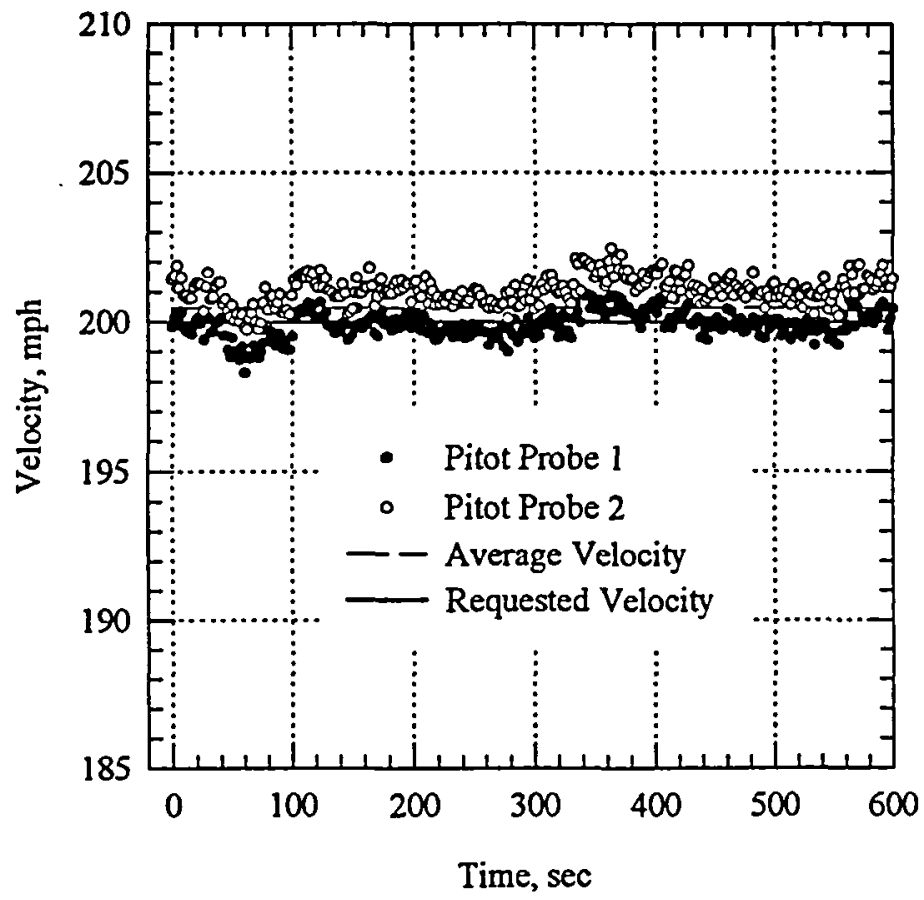

(a) Model not Shielded During Spray Start.

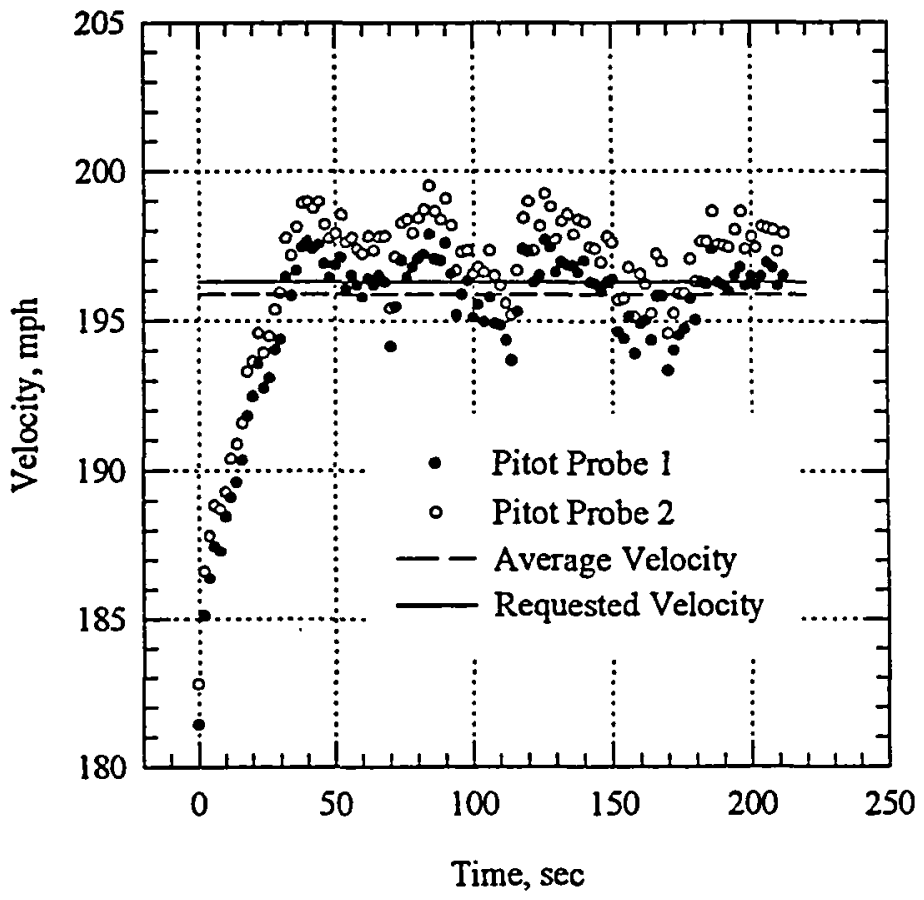

(b) Shielded Model. Shield Raised at 0 sec.

Figure 7. Typical Velocity History.

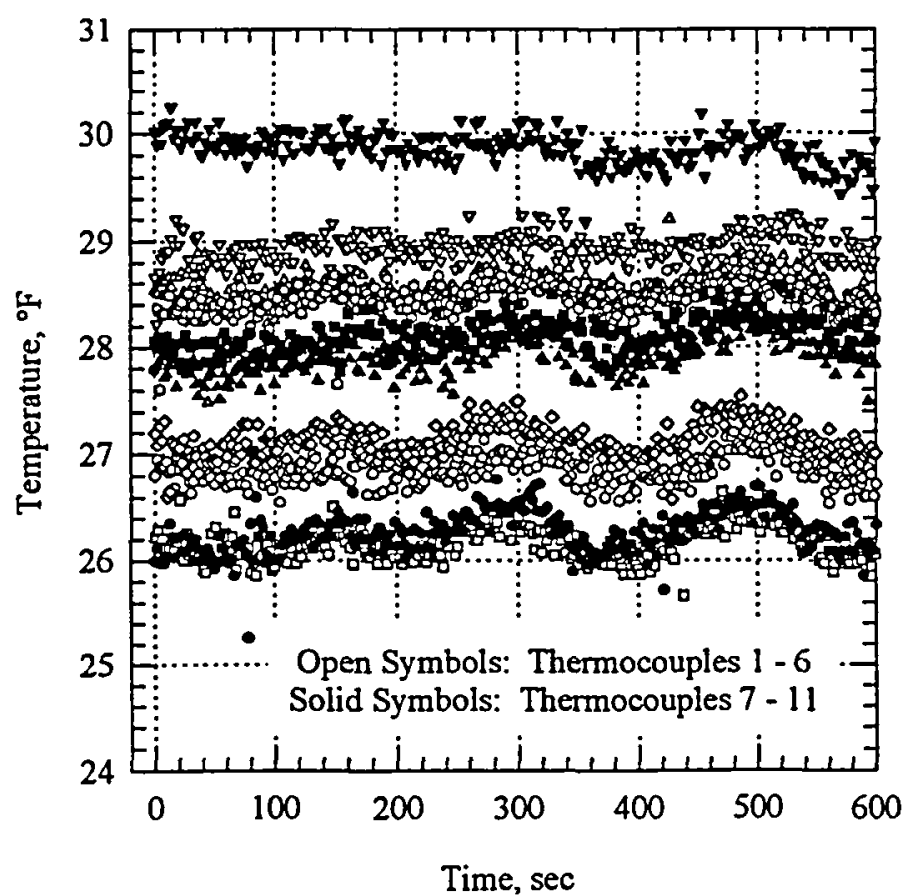

(a) Total Temperature, $-2.3^{\circ} \mathrm{C}\left(27.8^{\circ} \mathrm{F}\right)$.

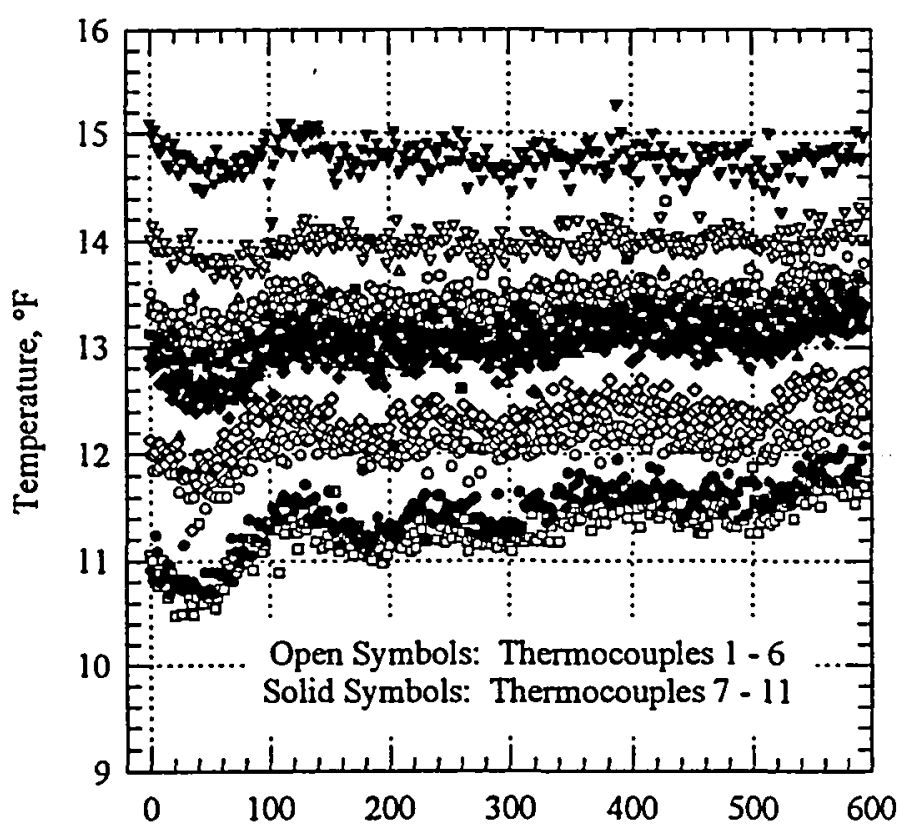

Time, sec

(b) Total Temperature, $-10.6^{\circ} \mathrm{C}\left(12.9^{\circ} \mathrm{F}\right)$.

Figure 8. Typical History of IIThermocouples at IRT Tuming Vane 'D'. 


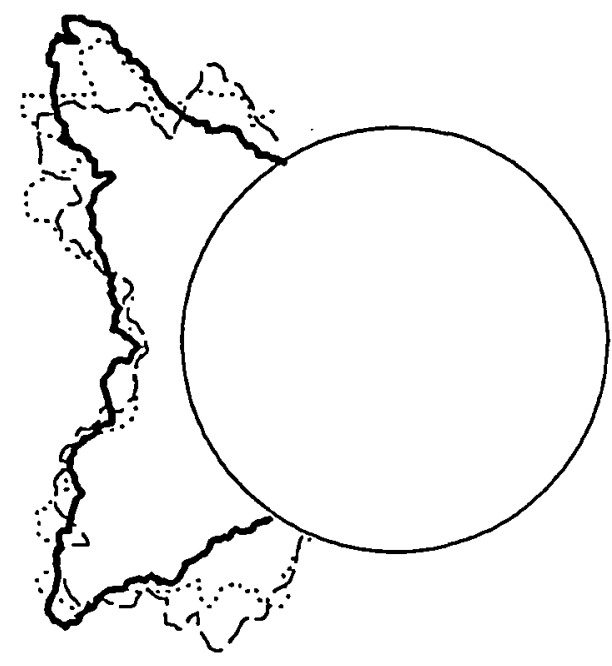

(a) Ice Shapes at Centerline.

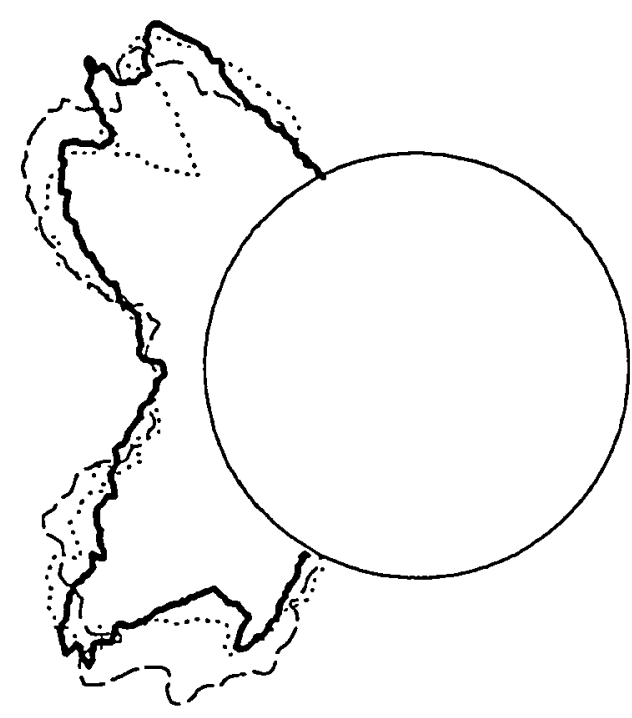

(b) Ice Shapes at 8 in Above Centerline.

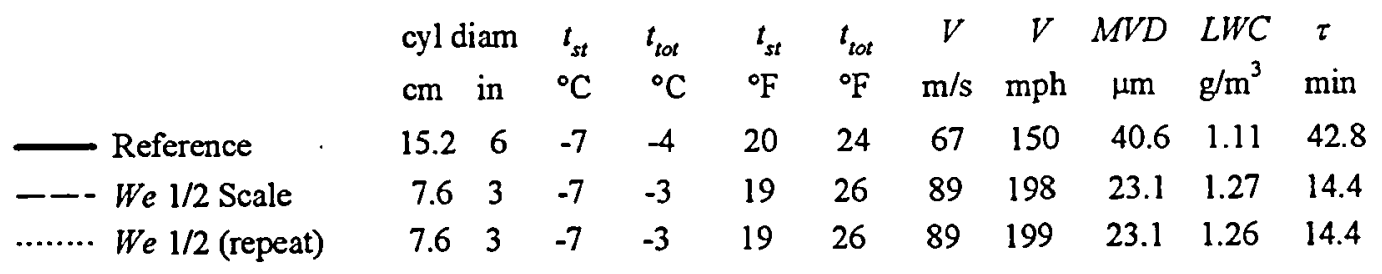

Figure 9. Constant-We Scaling Applied to Cylinders. Case I in Table I.

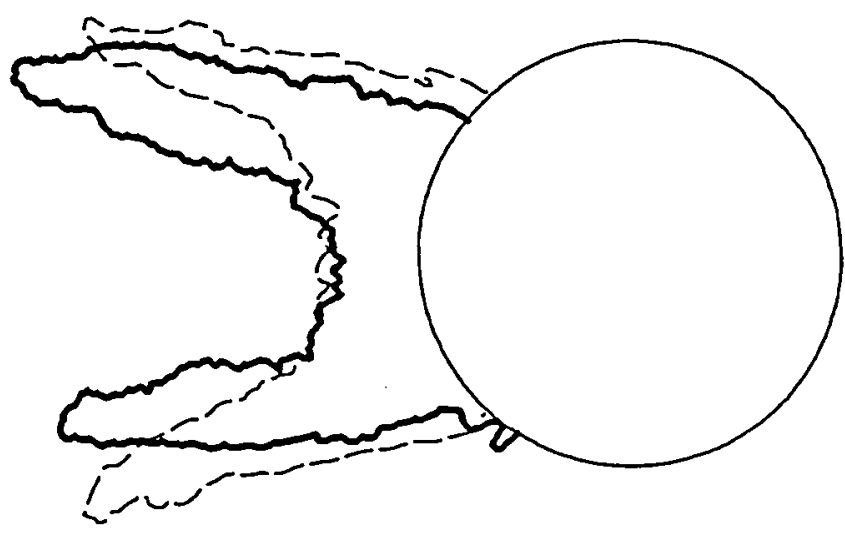

(a) Ice Shapes at Centerline.

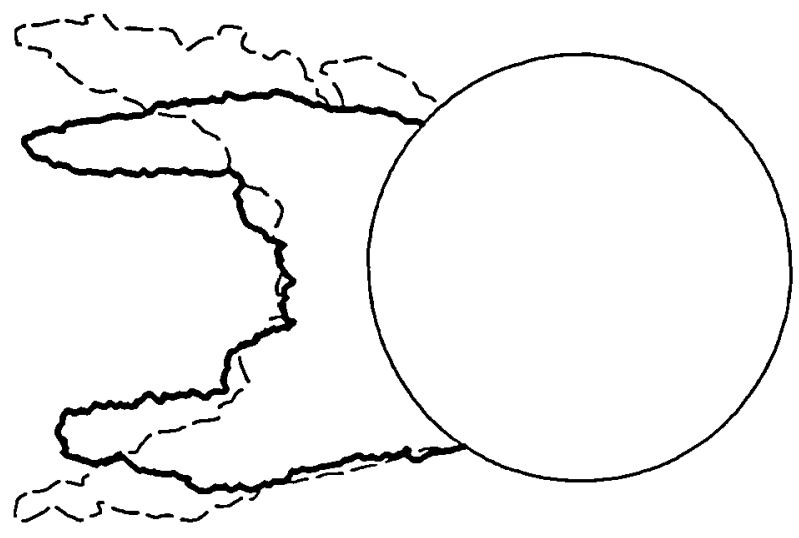

(b) Ice Shapes at 8 in Above Centerline.

\begin{tabular}{lccccccccccc} 
& \multicolumn{2}{c}{ cyl diam } & $t_{\text {st }}$ & $t_{\text {tot }}$ & $t_{\text {st }}$ & ${ }_{t \text { tot }}$ & $V$ & $V$ & $M V D$ & $L W C$ & $\tau$ \\
& $\mathrm{cm}$ & in & ${ }^{\circ} \mathrm{C}$ & ${ }^{\circ} \mathrm{C}$ & ${ }^{\circ} \mathrm{F}$ & ${ }^{\circ} \mathrm{F}$ & $\mathrm{m} / \mathrm{s}$ & $\mathrm{mph}$ & $\mu \mathrm{m}$ & $\mathrm{g} / \mathrm{m}^{3}$ & $\mathrm{~min}$ \\
- Reference & 15.2 & 6 & -12 & -8 & 10 & 17 & 90 & 200 & 40.7 & .88 & 40.3 \\
- - We 1/2 Scale & 7.6 & 3 & -13 & -6 & 9 & 22 & 119 & 266 & 23.6 & .97 & 13.8
\end{tabular}

Figure 10. Constant-We Scaling Applied to Cylinders. Case 2 in Table I. 


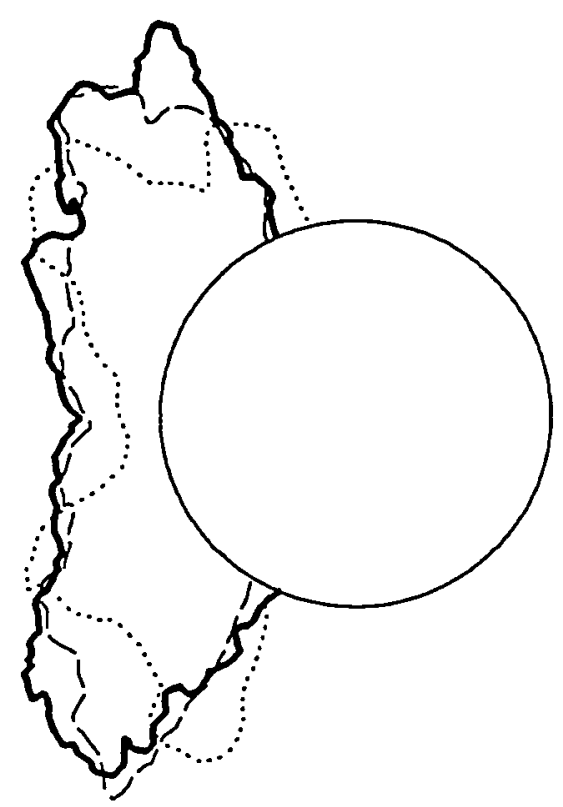

(a) Ice Shapes at Centerline.

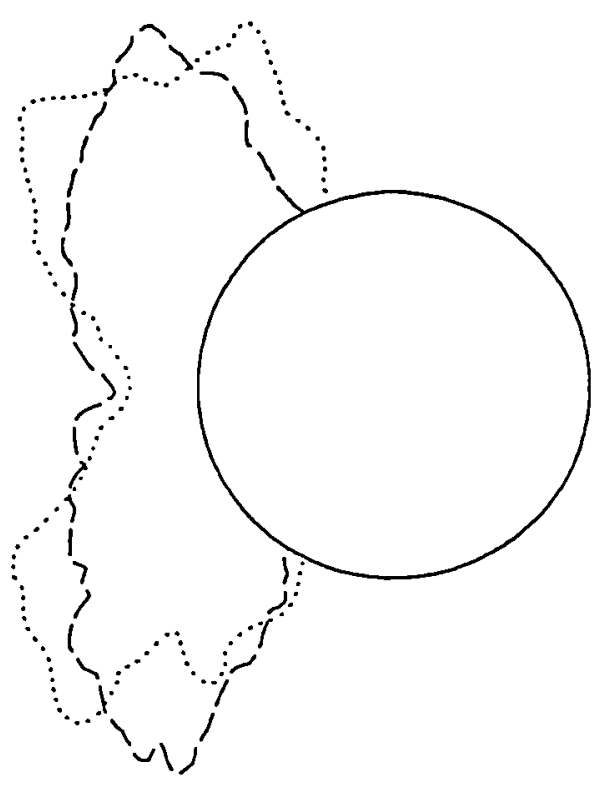

(b) Ice Shapes at 8 in Above Centerline.

\begin{tabular}{lccccccccccc} 
& $c y l$ diam & $t_{s t}$ & $t_{\text {tot }}$ & $t_{s t}$ & $t_{\text {tot }}$ & $V$ & $V$ & $M V D$ & $L W C$ & $\tau$ \\
& $\mathrm{cm}$ & in & ${ }^{\circ} \mathrm{C}$ & ${ }^{\circ} \mathrm{C}$ & ${ }^{\circ} \mathrm{F}$ & ${ }^{\circ} \mathrm{F}$ & $\mathrm{m} / \mathrm{s}$ & $\mathrm{mph}$ & $\mu \mathrm{m}$ & $\mathrm{g} / \mathrm{m}^{3}$ & $\mathrm{~min}$ \\
\hline - Reference & 7.6 & 3 & -7 & -4 & 20 & 24 & 67 & 151 & 58.0 & .89 & 26.7 \\
- - We 2/3 Scale & 5.1 & 2 & -7 & -4 & 20 & 25 & 79 & 177 & 42.7 & .95 & 14.2 \\
We $1 / 3$ Scale & 2.5 & 1 & -7 & -2 & 19 & 28 & 103 & 230 & 25.0 & 1.03 & 5.0
\end{tabular}

Figure 11. Constant-We Scaling Applied to Cylinders. Case 3 in Table I.

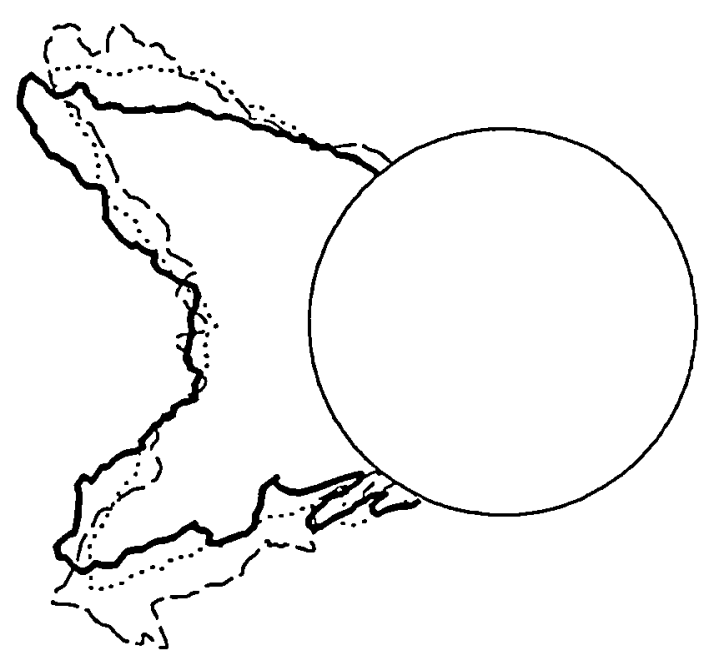

(a) Ice Shapes at Centerline.

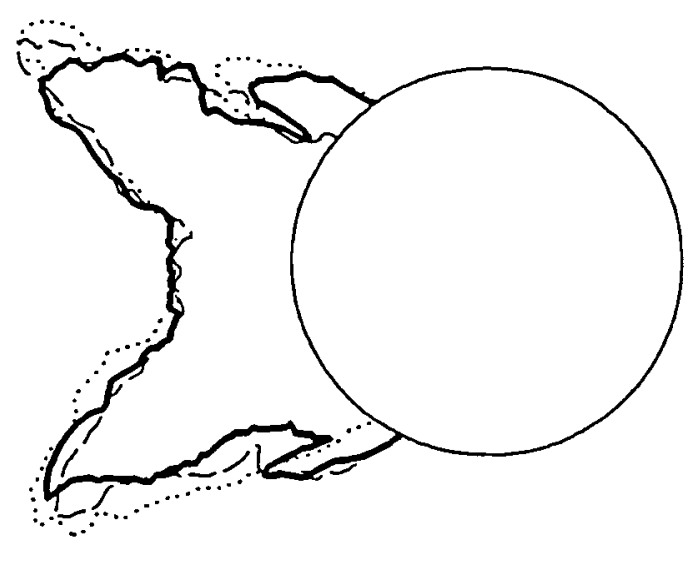

(b) Ice Shapes at 8 in Above Centerline.

\begin{tabular}{lccccccccccc} 
& \multicolumn{2}{c}{$\mathrm{cyl} \mathrm{diam}$} & $t_{\text {st }}$ & $t_{\text {tot }}$ & $\boldsymbol{t}_{\text {st }}$ & $\boldsymbol{t}_{\text {tot }}$ & $V$ & $V$ & $M V D$ & $L W C$ & $\tau$ \\
& $\mathrm{cm}$ & in & ${ }^{\circ} \mathrm{C}$ & ${ }^{\circ} \mathrm{C}$ & ${ }^{\circ} \mathrm{F}$ & ${ }^{\circ} \mathrm{F}$ & $\mathrm{m} / \mathrm{s}$ & $\mathrm{mph}$ & $\mu \mathrm{m}$ & $\mathrm{g} / \mathrm{m}^{3}$ & $\mathrm{~min}$ \\
\hline - Reference & 7.6 & 3 & -9 & -7 & 15 & 19 & 67 & 150 & 40.0 & .80 & 26.8 \\
-- Reference (repeat) & 7.6 & 3 & -9 & -7 & 15 & 19 & 67 & 150 & 39.9 & .80 & 26.8 \\
- - We 2/3 Scale & 5.1 & 2 & -10 & -7 & 14 & 20 & 79 & 177 & 28.7 & .88 & 14.3
\end{tabular}

Figure 12. Constant-We Scaling Applied to Cylinders. Case 4 in Table I. 


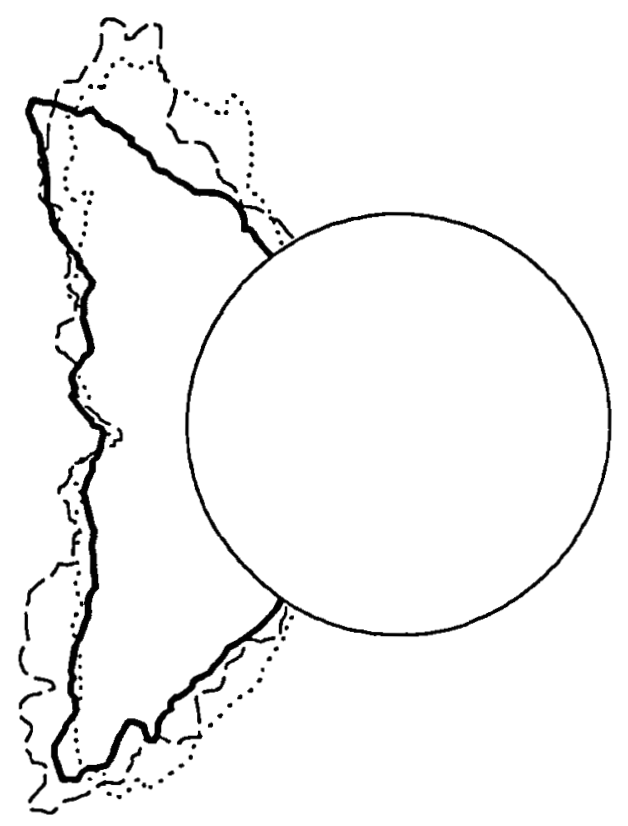

(a) Ice Shapes at Centerline.

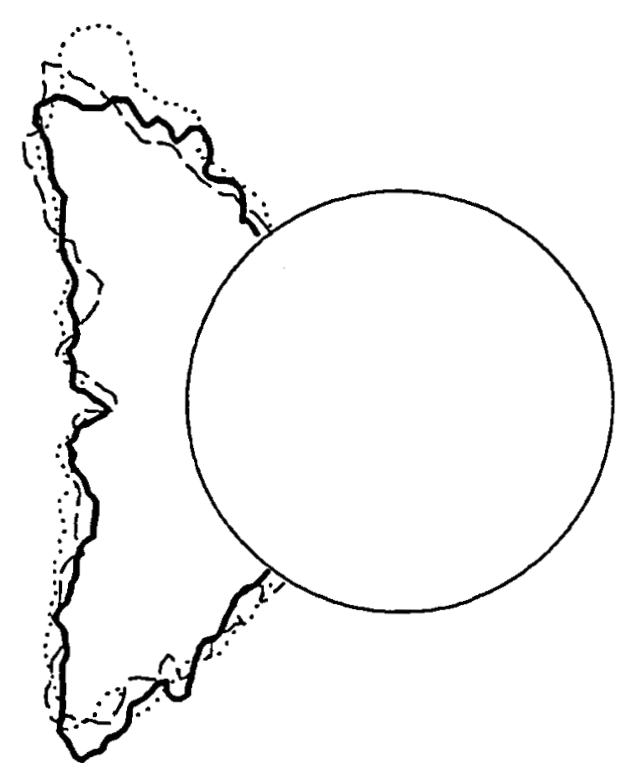

(b) Ice Shapes at 8 in Above Centerline.

\begin{tabular}{|c|c|c|c|c|c|c|c|c|c|c|}
\hline & cyl diam & $t_{s t}$ & $t_{t o t}$ & $t_{s t}$ & $t_{\text {tot }}$ & & $V$ & $M V D$ & $\begin{array}{l}L W C \\
3\end{array}$ & $\tau$ \\
\hline & $\mathrm{cm}$ & ${ }^{\circ} \mathrm{C}$ & ${ }^{\circ} \mathrm{C}$ & ${ }^{\circ} \mathrm{F}$ & ${ }^{\circ} \mathrm{F}$ & $\mathrm{m} / \mathrm{s}$ & $\mathrm{mph}$ & $\mu \mathrm{m}$ & & $\min$ \\
\hline Reference & 7.63 & -7 & -4 & 20 & 24 & 67 & 150 & 40.5 & .80 & 26.8 \\
\hline nce (repeat) & 7.63 & -7 & -4 & 20 & 24 & 67 & 150 & 39.1 & .80 & 26.8 \\
\hline We 2/3 Scale & 5.12 & -7 & -4 & 20 & 25 & 79 & 177 & 28.8 & .86 & 14.4 \\
\hline
\end{tabular}

Figure 13. Constant-We Scaling Applied to Cylinders. Case 5 in Table I.
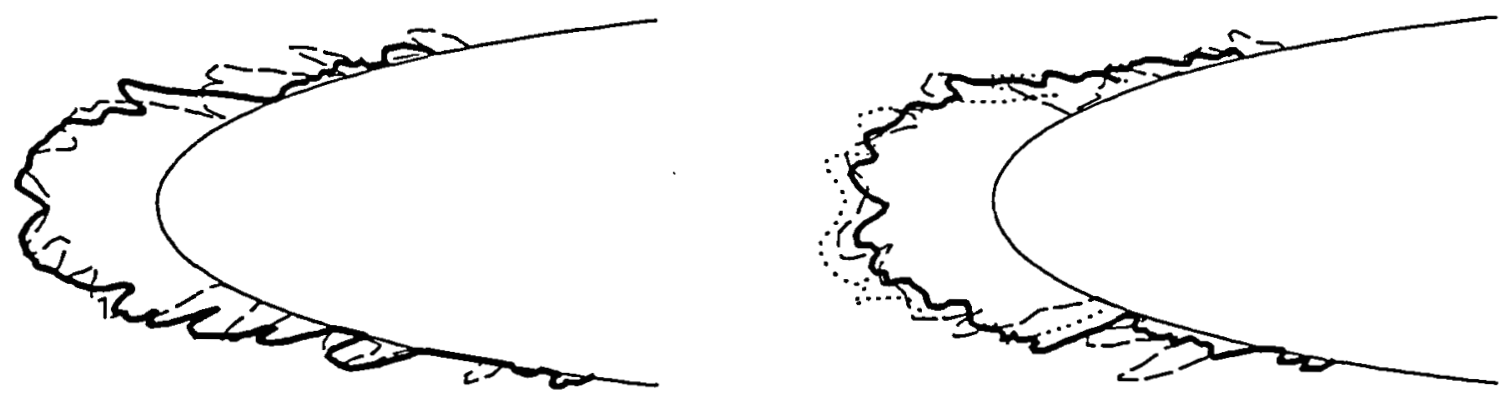

(a) Ice Shapes at Centerline.

(b) Ice Shapes at 8 in Above Centerline.

\begin{tabular}{|c|c|c|c|c|c|c|c|c|c|c|c|}
\hline & \multicolumn{2}{|c|}{ chord } & \multirow{2}{*}{$\begin{array}{l}t_{s t} \\
{ }^{\circ} \mathrm{C}\end{array}$} & \multirow{2}{*}{$\begin{array}{l}t_{\text {tot }} \\
{ }^{\circ} \mathrm{C}\end{array}$} & \multirow{2}{*}{$\begin{array}{l}t_{s t} \\
{ }^{\circ} \mathrm{F}\end{array}$} & \multirow{2}{*}{$\begin{array}{l}t_{t o t} \\
{ }^{\circ} \mathrm{F}\end{array}$} & \multirow{2}{*}{$\begin{array}{c}V \\
\mathrm{~m} / \mathrm{s}\end{array}$} & \multirow{2}{*}{$\begin{array}{c}V \\
\mathrm{mph}\end{array}$} & \multirow{2}{*}{$\begin{array}{c}M V D \\
\mu \mathrm{m}\end{array}$} & \multirow{2}{*}{$\begin{array}{l}L W C \\
\mathrm{~g} / \mathrm{m}^{3}\end{array}$} & \multirow{2}{*}{$\begin{array}{l}\tau \\
\min \end{array}$} \\
\hline & $\mathrm{cm}$ & in & & & & & & & & & \\
\hline & 53.3 & 21 & -15 & -11 & 6 & 13 & 90 & 200 & 40.4 & .55 & 9.9 \\
\hline & 26.7 & 10.5 & -15 & -8 & 4 & 17 & 117 & 263 & 23.0 & .62 & 3.4 \\
\hline We $1 / 3$ Scale & 17.8 & 7 & -16 & -6 & 4 & 21 & 138 & 309 & 16.6 & .64 & 1.8 \\
\hline
\end{tabular}

Figure 14. Constant-We Scaling Applied to NACA 0012 Airfoils. Case 6 in Table I. 

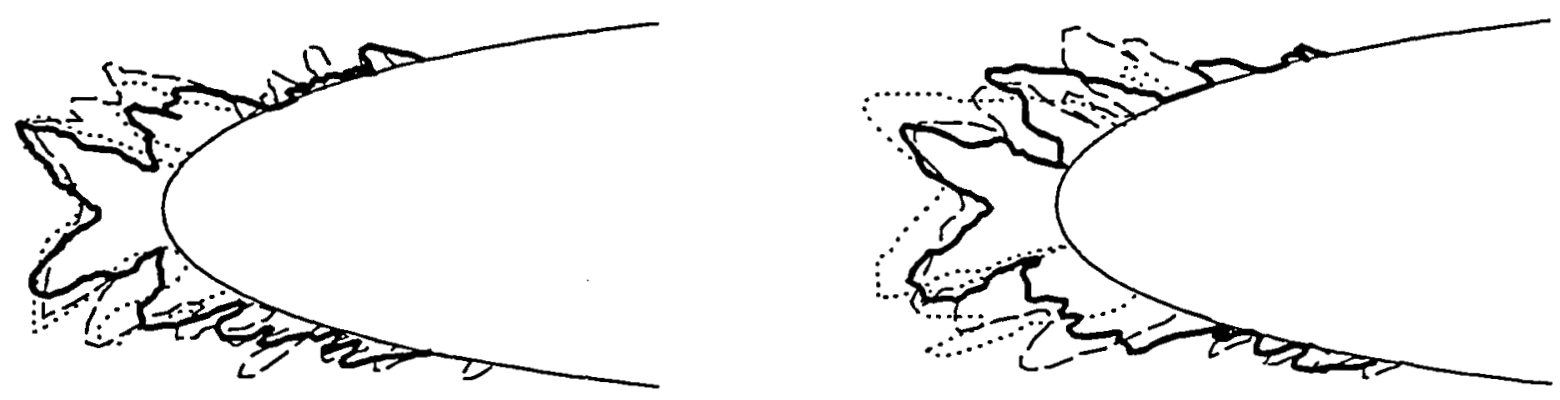

(a) Ice Shapes at Centerline.

(b) Ice Shapes at 8 in Above Centerline.

\begin{tabular}{|c|c|c|c|c|c|c|c|c|c|c|c|}
\hline & \multicolumn{2}{|c|}{ chord } & $t_{s t}$ & $t_{t o t}$ & $t_{s t}$ & $t_{\text {tot }}$ & $V$ & $V$ & $M V D$ & $L W C$ & $\tau$ \\
\hline & $\mathrm{cm}$ & in & ${ }^{\circ} \mathrm{C}$ & ${ }^{\circ} \mathrm{C}$ & ${ }^{\circ} \mathrm{F}$ & ${ }^{\circ} \mathrm{F}$ & $\mathrm{m} / \mathrm{s}$ & $\mathrm{mph}$ & $\mu \mathrm{m}$ & $\mathrm{g} / \mathrm{m}^{3}$ & $\min$ \\
\hline & 53.3 & 21 & -12 & -8 & 10 & 17 & 90 & 200 & 40.5 & .55 & 9.9 \\
\hline & 26.7 & 10.5 & -12 & -5 & 10 & 22 & 118 & 263 & 23.0 & .61 & 3.4 \\
\hline We $1 / 3$ Scale & 17.8 & 7 & -13 & -4 & 8 & 26 & 138 & 310 & 16.6 & 62 & \\
\hline
\end{tabular}

Figure 15. Constant-We Scaling Applied to NACA 0012 Airfoils. Case 7 in Table I.
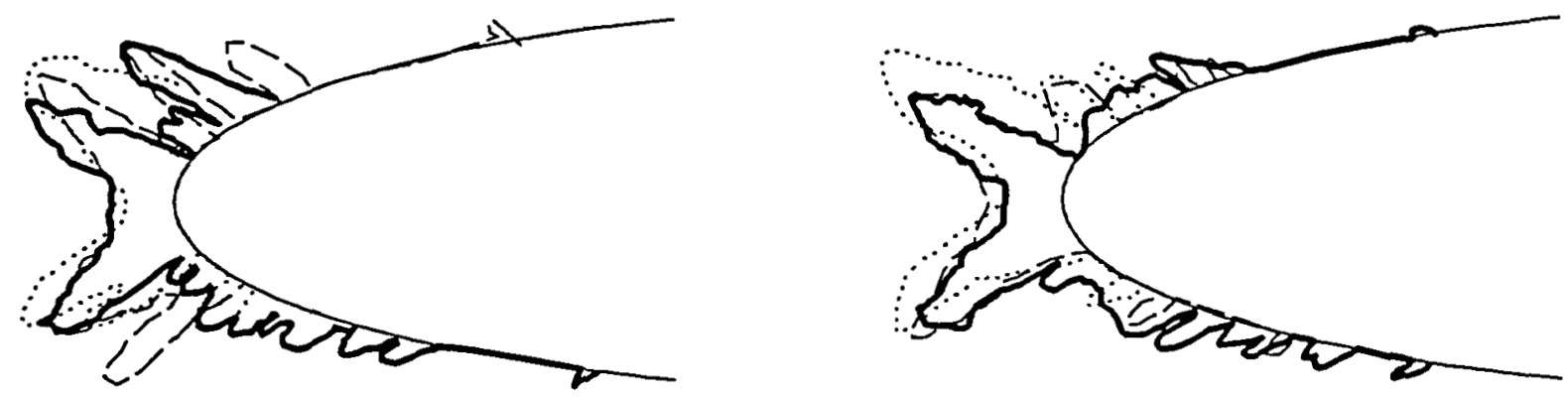

(a) Ice Shapes at Centerline.

(b) Ice Shapes at 8 in Above Centerline.

\begin{tabular}{lccccccccccc} 
& \multicolumn{2}{c}{ chord } & $t_{s t}$ & $t_{\text {tot }}$ & $t_{s t}$ & $t_{\text {tot }}$ & $V$ & $V$ & $M V D$ & $L W C$ & $\tau$ \\
& $\mathrm{cm}$ & in & ${ }^{\circ} \mathrm{C}$ & ${ }^{\circ} \mathrm{C}$ & ${ }^{\circ} \mathrm{F}$ & ${ }^{\circ} \mathrm{F}$ & $\mathrm{m} / \mathrm{s}$ & $\mathrm{mph}$ & $\mu \mathrm{m}$ & $\mathrm{g} / \mathrm{m}^{3}$ & $\mathrm{~min}$ \\
\hline - Reference & 53.3 & 21 & -9 & -5 & 16 & 23 & 89 & 200 & 40.6 & .55 & 10.0 \\
- We $1 / 2$ Scale & 26.7 & 10.5 & -10 & -3 & 14 & 27 & 118 & 263 & 23.0 & .59 & 3.5 \\
We $1 / 3$ Scale & 17.8 & 7 & -10 & -1 & 13 & 30 & 138 & 310 & 16.7 & .58 & 2.0
\end{tabular}

Figure 16. Constant-We Scaling Applied to NACA 0012 Airfoils. Case 8 in Table I. 

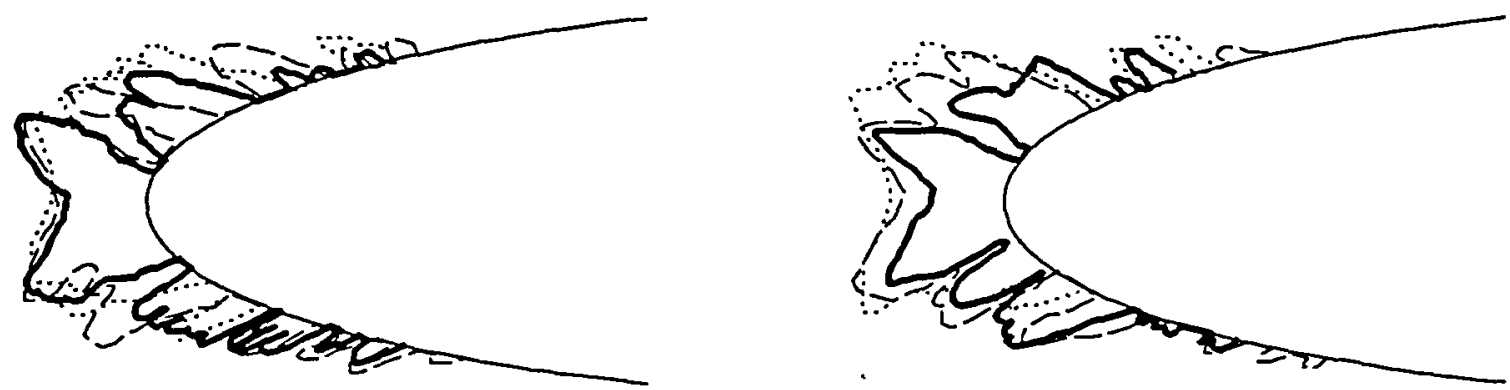

(a) Ice Shapes at Centerline.

(b) Ice Shapes at 8 in Above Centerline.

\begin{tabular}{|c|c|c|c|c|c|c|c|c|c|c|c|}
\hline & \multicolumn{2}{|c|}{ chord } & $t_{s t}$ & $t_{t o t}$ & $t_{s t}$ & $t_{t o t}$ & $V$ & $V$ & $M V D$ & $L W C$ & $\tau$ \\
\hline & cm & in & ${ }^{\circ} \mathrm{C}$ & ${ }^{\circ} \mathrm{C}$ & ${ }^{\circ} \mathrm{F}$ & ${ }^{\circ} \mathrm{F}$ & $\mathrm{m} / \mathrm{s}$ & $\mathrm{mph}$ & $\mu \mathrm{m}$ & $\mathrm{g} / \mathrm{m}^{3}$ & $\min$ \\
\hline eference & 53.3 & 21 & -11 & -8 & 13 & 17 & 67 & 150 & 41.0 & .65 & 11.2 \\
\hline We $1 / 2$ & 26.7 & 10.5 & -11 & -8 & 12 & 19 & 88 & 196 & 23.4 & .76 & 3.7 \\
\hline$\cdots W e$ 1/3 Scale & 17.8 & 7 & -12 & -6 & 11 & 21 & 103 & 230 & 16.9 & 81 & 2.0 \\
\hline
\end{tabular}

Figure 17. Constant-We Scaling Applied to NACA 0012 Airfoils. Case 9 in Table I.

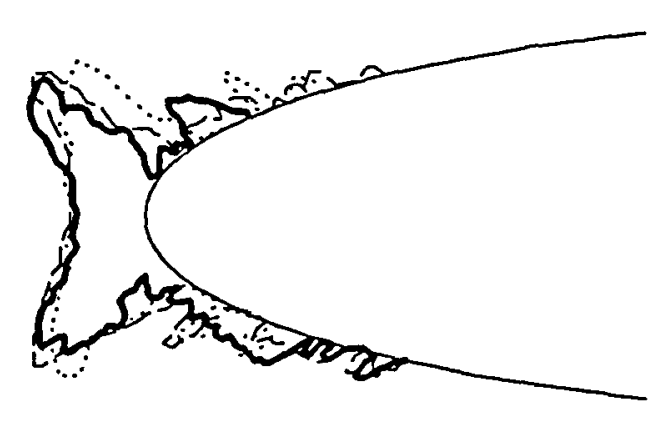

(a) Ice Shapes at Centerline.

\begin{tabular}{ccccccccccc}
\multicolumn{2}{c}{ chord } & $t_{s t}$ & $t_{\text {tot }}$ & $t_{s t}$ & $t_{t o t}$ & $V$ & $V$ & $M V D$ & $L W C$ & $\tau$ \\
$\mathrm{cm}$ & in & ${ }^{\circ} \mathrm{C}$ & ${ }^{\circ} \mathrm{C}$ & ${ }^{\circ} \mathrm{F}$ & ${ }^{\circ} \mathrm{F}$ & $\mathrm{m} / \mathrm{s}$ & $\mathrm{mph}$ & $\mu \mathrm{m}$ & $\mathrm{g} / \mathrm{m}^{3}$ & $\mathrm{~min}$ \\
53.3 & 21 & -8 & -6 & 17 & 21 & 67 & 150 & 40.7 & .65 & 11.2 \\
26.7 & 10.5 & -8 & -5 & 17 & 24 & 88 & 196 & 23.2 & .74 & 3.7 \\
17.8 & 7 & -9 & -4 & 16 & 26 & 103 & 231 & 16.9 & .78 & 2.0
\end{tabular}

Figure 18. Constant-We Scaling Applied to NACA 0012 Airfoils. Case 10 in Table I. 
Public reporting burden for this collection of information is estimated to average 1 hour per response, including the time tor reviewing instructions, searching existing data sources. gathering and maintaining the data needed, and completing and reviewing the collection of information. Send comments regarding this burden estimate or any other aspect of this collection of information, including suggestions for reducing this burden. to Washington Heacquarters Services. Directorate for Intormation Operations and Reports, 1215 Jefferson Davis Highway, Suke 1204, Arlington. VA 22202-4302, and to the Office of Management and Budget, Papenwork Reduction Project (0704-0188). Washington, DC 20503.

\begin{tabular}{l|l|l|} 
1. AGENCY USE ONLY (Leave blank) & 2. REPORT DATE & 3. REPORT TYPE AND DATES COVERED
\end{tabular}

\begin{tabular}{|l|l|l} 
1. January 1996 & Technical Memorandum \\
\hline
\end{tabular}

\section{TITLE AND SUBTITLE}

Evaluation of Constant-Weber-Number Scaling for Icing Tests

6. AUTHOR(S)

David N. Anderson

7. PERFORMING ORGANIZATION NAME(S) AND ADDRESS(ES)

National Aeronautics and Space Administration

Lewis Research Center

Cleveland, Ohio 44135-3191

9. SPONSORING/MONITORING AGENCY NAME(S) AND ADDRESS(ES)

National Aeronautics and Space Administration

Washington, D.C. 20546-0001
5. FUNDING NUMBERS

WU-505-68-10

8. PERFORMING ORGANIZATION REPORT NUMBER

E-10071

10. SPONSORINGMONITORING AGENCY REPORT NUMBER

NASA TM-107141

AIAA-96-0636

11. SUPPLEMENTARY NOTES

Prepared for the 34th Aerospace Sciences Meeting and Exhibit sponsored by the American Institute of Aeronautics and Astronautics, Reno, Nevada, January 15-18, 1996. Responsible person, David N. Anderson, organization code 2720, (210) 433-3585.

12a. DISTRIBUTIONAVAILABILTTY STATEMENT

12b. DISTRIBUTION CODE

Unclassified - Unlimited

Subject Category 03

This publication is available from the NASA Center for Aerospace Information, (301) 621-0390.

13. ABSTRACT (Maximum 200 words)

Previous studies showed that for conditions simulating an aircraft encountering super-cooled water droplets the droplets may splash before freezing. Other surface effects dependent on the water surface tension may also influence the iceaccretion process. Consequently, the Weber number appears to be important in accurately scaling ice accretion. A scaling method which uses a constant-Weber-number approach has been described previously; this study provides an evaluation of this scaling method. Tests are reported on cylinders of 2.5 to $15-\mathrm{cm}$ diameter and NACA 0012 airfoils with chords of 18 to $53 \mathrm{~cm}$ in the NASA Lewis Icing Research Tunnel (IRT). The larger models were used to establish reference ice shapes, the scaling method was applied to determine appropriate scaled test conditions using the smaller models, and the ice shapes were compared. Icing conditions included warm glaze, hom glaze and mixed. The smallest size scaling attempted was $1 / 3$, and scale and reference ice shapes for both cylinders and airfoils indicated that the constant-Weber-number scaling method was effective for the conditions tested.

\begin{tabular}{|c|c|c|}
\hline $\begin{array}{c}\text { 14. SUBJECT TERMS } \\
\text { Scaling; Icing }\end{array}$ & $\begin{array}{c}\text { 19. SECURITY CLASSIFICATION } \\
\text { OF ABSTRACT } \\
\text { Unclassified }\end{array}$ \\
\hline $\begin{array}{c}\text { 17. SECURITY CLASSIFICATION } \\
\text { OF REPORT } \\
\text { Unclassified }\end{array}$ & $\begin{array}{c}\text { 18. SECURTY CLASSIFICATION } \\
\text { OF THIS PAGE } \\
\text { Unclassified }\end{array}$ &
\end{tabular}


National Aeronautics and

Space Administration

Lewis Research Center

21000 Brookpark Rd.

Cleveland, OH 44135-3191

Officlal Business

Penalty for Private Use $\$ 300$

POSTMASTER: If Undeliverable - Do Not Return

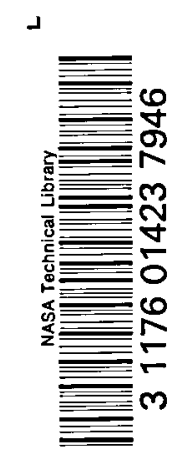

